ACTA THERIOLOGICA

Vol. 21, 31: 425-468, 1976

\title{
Arvicola richardsoni: Ecology and Biochemical Polymorphism in the Front Ranges of Southern Alberta
}

\author{
Paul K. ANDERSON, Paul H. WHITNEY \& Jean-Pierre HUANG
}

\begin{abstract}
Anderson P. K., Whitney P. H. \& Huang J. -P., 1976: Arvicola richardsoni: ecology and biochemical polymorphism in the front ranges of southern Alberta. Acta theriol., 21, 31: 425-468 [With 10 Tables \& 7 Figs.].

In Alberta Arvicola richardsoni (DeKay, 1842) are generally restricted to mesic habitats within a few meters of spring-fed streams at elevations of 2000 to 2200 meters in the Rocky Mountain front ranges. This habitat specialization defines the distribution and size of local populations, and dispersion within those populations. At two sites where populations were studied six other small rodent species (four of them microtines) also occur. All have wider geographic and ecological distributions than does Arvicola richardsoni. Ecological and geographical distributions of $A$. terrestris and $A$. richardsoni are compared and possible explanations for the restricted distribution of A. richardsoni are considered. Examination of plants cut and bathered by $A$. richardsoni suggested that forbs were more important than grasses in the summer diet. In 1972 , breeding occurred from June through August, probably terminating in early September. Overwintered adult females produced three litters. In the sample studied all members of the first litter of the season were female. Females of the first litter of the 19.72 season were pregnant in August of that year. Catch per trap-hour was used as an index of relative density and increased 200 to $300 \%$ between early July and late August. August densities were 17.6 and 32.5 individuals/hectare. Animals were active throughout the diel cycle. Activity was lowest between dawn and mid-day and highest during the hours of darkness. Routine movements were greater in adult males than in adult females. In the August population recently weaned young showed the least vagility. Composition of August populations is described and suggestions are mede with respect to social organization and integration. The populations studied were polymorphic at loci controlling leucine aminopeptidase plasma esterases and red-cell esterases. No variability was detected in transferrins, hemoglobins, or glucosephosphate isomerases. The level of intrapopulation variability appears to be relatively high, compared with that in other rodent species, despite subdivision of the population into small groups isolated in small islands of favorable habitat. It is suggested that this may be a consequence of adaptive requirements, imposed by a seasonally variable environment, which override any tendencies toward reduced variability arising through population structuring.
\end{abstract}

[Dept. Biol., Univ. of Calgary, Canada]

\section{INTRODUCTION}

Theories about the dynamics and evolutionary strategies of small mammal populations have been developed primarily on the basis of

[425] 
data collected on widely distributed species, abundant in easily accessible local communities. It is generally assumed that these populations are representative, but this assumption cannot yet be validated. Richardson's vole, Arvicola richardsoni, is one of the less well known rodent species of the mountains of western North America. The habitat and distribution of this species suggest that its population attributes may be distinctive, and it is this possibility which has motivated our study.

We report here a summary of exploratory trapping between 1963 and 1971 , and the results of two periods of intensive study (July $4-8$ and August 21-29, 1972) at Highwood Pass and Plateau Mountain in the Canadian Rockies (Fig. 1).

\section{METHODS}

In the exploratory trapping both snap traps (Museum Special and Victor mouse traps) and live traps (Sherman and Longworth) were used. In 1972 we evolved and standardized our methods as follows. Animals were livetrapped in $26 \mathrm{~cm}$ long Sherman folding traps, supplied with cotton batting and rolled oats. Initially traps were set approximately five meters apart beside, or up to 20 meters away from, mountain streams. With further experience we decided the best procedure was to work along the stream banks, systematically searching for signs of microtine activity. Traps were set wherever characteristic and apparently active runways, freshly cut vegetation, or fresh feces were observed. Wo found that such signs were aggregated and intermittent. We therefore standardized at sets of five traps on or within one meter of the stream bank in each zone of activity. When traps had been set, linear distances between traps along the strcam were measured and recorded, both within and between zones of activity. This procedure was developed during the July trapping period and was used consistently in the August, 1972 trapping. In addition to traps so placed, we set occasional transect lines, perpendicular to the stream, to evaluate the distance to which the voles were active away from the stream margin. The microtopography, evidences of vole activity, and vegetation were recorded for each trap station. Vegetation was characterized in terms of the presence, height, and density of each of the subjectively more common plant species. Vegetation clipped by the voles and piled in burrow entrances or scattered along runways was collected for identification and the cut segments assignable to each plant species werc counted. At Plateau Mountain the fresh weight of such cuttings was also taken.

Traps were checked at intervals of approximately six hours, day and night. Captured animals were ear-tagged. Body length from the tip of the snout to the base of the tail was measured by stretching the animal along a $30 \mathrm{~cm}$ ruler. Where an animal was measured repeatedly the maximum length measured was used in analysis of data. Weight was taken by hanging the animal by its tail from a spring clip on a Pessola spring scale. External indications of reproductive status were noted. Blood was collected from an orbital sinus in heparinized tubes (1.1$1.2 \mathrm{~mm}$ I. D.). The blood samples were kept refrigerated in thermos flasks, stored in snowbanks (July) or in ice-filled styrofoam coolers (August) for one to three days before centrifuging. Capillary tubes were centrifuged for 20 minutes at approximately $400 \mathrm{~g}$ to separate plasma from erythrocytes. Erythrocytes were 
washed three times in a sodium citrate solution, and lysed with two drops of distilled water. Prior to electrophoresis for transferrin and esterases, samples were stored in the laboratory at $-20^{\circ} \mathrm{C}$ for one to three months. Samples run for leucine aminopeptidase, hemogiobin, and glucosephosphate isomerase were held for approximately six months prior to electrophoresis.

In electrophoresis the horizontal starch gel system, modified after $\mathrm{K} r$ is t-

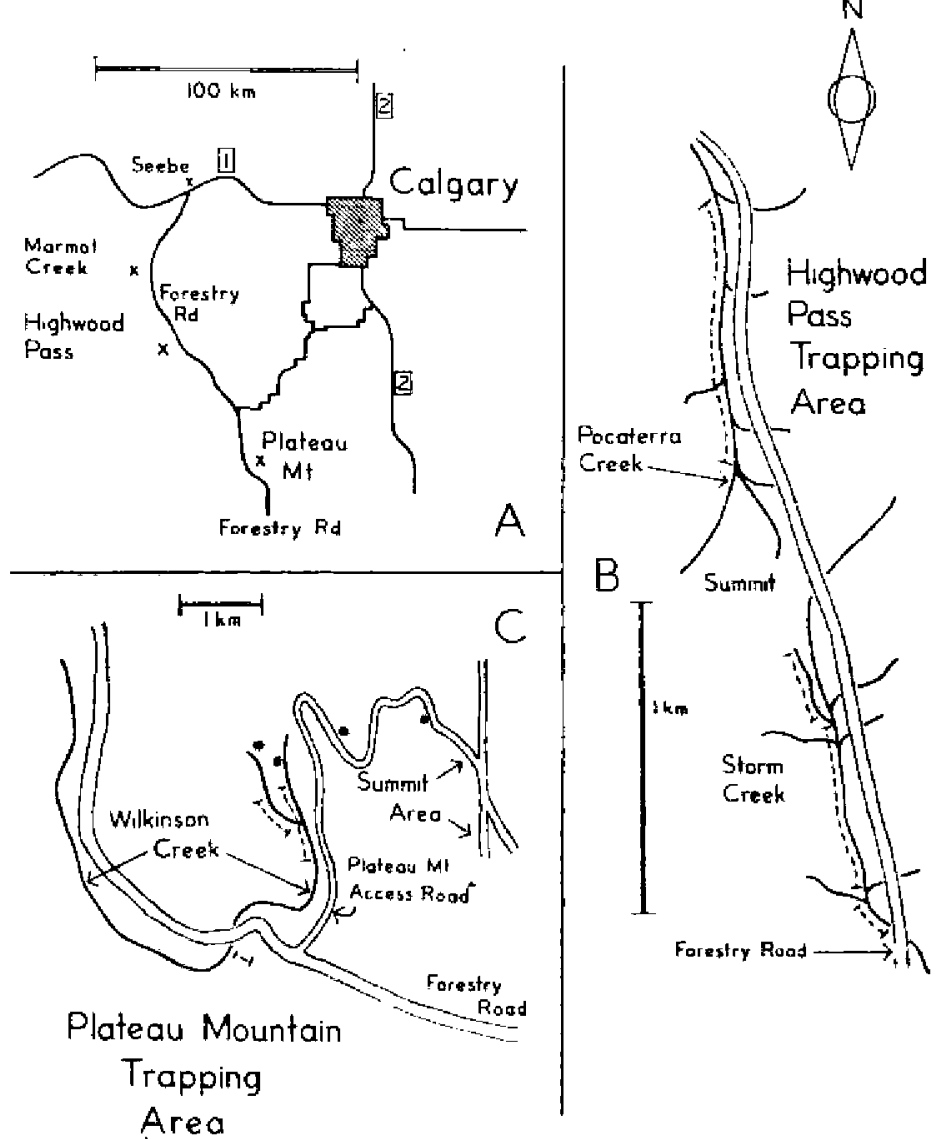

Fig. 1. Fig. 1A shows the locaiions of Marmot Creek, Highwood Pass, and Platean Mountain with reference to the City of Calgary. Fig. 1B locates trapping areas along Pocaterra Creek and Storm Creek at Highwood Pass. Fig. IC locatez trapping areas at Plateau Mountain. Dotted lines indicate extent of successful trap lines. Asterisks indicate sites where traps were set, but where no A. richardsoni were captured and no characteristic sign was found.

jans on (1963) was used. Gels were prepared two at a time by suspending $60 \mathrm{~g}$ of hydrolyzed starch (Connaught Medical Laboratories Starch Lot 281-2) in 500 cc of the appropriate buffer (see Table 1). After pouring, the gels were allowed to cool under refrigeration at $4^{\circ} \mathrm{C}$ for approximately 30 minutes. Samples in whatman No. 3 filter paper strips $(1 \mathrm{~cm} \times 0.5 \mathrm{~cm})$ were inserted into pre-cut slots either 
Table 1

Protein systems, buffers, and stains.

\begin{tabular}{|c|c|c|c|c|c|c|}
\hline T'rotein system & Source & Gel buffer & Electrolyte buffer & $\begin{array}{l}\text { Insert line } \\
\text { (Aistance } \\
\text { from } \\
\text { cathode) }\end{array}$ & $\begin{array}{l}\text { Direction } \\
\text { of } \\
\text { migration }\end{array}$ & Stain \\
\hline Transferrin & Plasma & Tris-citrate $\mathrm{pH} 7.2$ & Sodjum borate pH 8.7 & $4 \mathrm{~cm}$ & Anode & Buffalo black \\
\hline Plasma esterases & Plasma & Tris-citrate $\mathrm{pH} 7.2$ & Sodium borate pII 8.7 & $4 \mathrm{~cm}$ & Anode & «-naphthyl-acetate \\
\hline $\begin{array}{l}\text { Red cell } \\
\text { esterases }\end{array}$ & RBC & Tris-citrate $\mathrm{pH} 7.6$ & Sodium borate $\mathrm{pH} 8.7$ & $4 \mathrm{~cm}$ & Anode & $\begin{array}{c}\alpha \text {-naphthyl-acetate } \\
\& \text { a-naphthyl-butyrate }\end{array}$ \\
\hline $\begin{array}{l}\text { Leucine amino } \\
\text { peptidase (LAP) }\end{array}$ & Plasma & Tris-citrate $\mathrm{pH} 7.6$ & Sodium borate pH 8.7 & $4 \mathrm{~cm}$ & Anode & LAP specific \\
\hline Hemoglobin & RBC & Tris-citrate $\mathrm{pH} 6.2$ & Tris-citrate $\quad$ pH 6.2 & $10 \mathrm{~cm}$ & Cathode & Buffalo black \\
\hline $\begin{array}{l}\text { Glucosephosphate } \\
\text { isomerase (GPI) }\end{array}$ & $\mathrm{RBC}$ & Tris-citrate $\mathrm{pH} 6.2$ & Tris-citrate & $10 \mathrm{~cm}$ & Cathode & GPI specific \\
\hline
\end{tabular}


4 or $10 \mathrm{~cm}$ from the cathodic end of the gel. Gels were then covered with Saran wrap to prevent desiccation and were run at approximately $4^{\circ} \mathrm{C}$ in refrigerators equipped with internal circulating fans to dissipate heat. For transferrins, esterases, and leucine aminopeptidase (LAP) a voltage gradient of 8 volts/cm (MA 22 \pm 2 ) was applied for 30 minutes. The filter paper inserts were then removed and a voltage gradient of 15 volts/cm (MA 32 \pm 2 ) was applied until the borate line had migrated $10.6 \mathrm{~cm}$ from the insert line. Total running time for these systems was four to five hours. For hemoglobin and glucosephosphate isomerase (GPI) a voltage gradient of 6.5 volts/cm (MA 15 12 ) was applied for 16 to 17 hours.

In preliminary tests of technique, several samples were screened for polymorphism over a series of $\mathrm{pH}$ values from 7.2 to 8.5 . Samples were then run at the values producing the best resolution.

After electrophoresis, gels were sliced hortzontally and stained. Following staining all gels were washed and fixed overnight in a $1: 5: 5$ solution of acetic acid. methanol, and distilled water. Transferrin bands were identified using the Canalco method as modified by Rasmussen \& Koehn (1966) and Rasmussen (pers. comm.). Preparation of buffers and stains for all systems is summarized in the appendix to this report.

\section{RESULTS}

\subsection{Exploratory Trapping}

In trapping a number of localities in and near the drainages of the Kananaskis, Elbow, and Highwood Rivers between 1963 and 1971, Arvicola richardsoni was encountered only in two areas in the Kananaskis drainage. In the upper basin of Marmot Creek, which enters the Kananaskis River approximately $20 \mathrm{~km}$ south of the junction with the Bow River at Seebe, Alberta, A. richardsoni was found in spring-fed streamside moss beds at timberline $(2195 \mathrm{~m}$ elevation), but appeared to be absent at lower $(1402-1982 \mathrm{~m})$ and higher $(2287-2744 \mathrm{~m})$ elevations. At Highwood Pass (elevation 2122 to $2207 \mathrm{~m}$ ), $68 \mathrm{~km}$ S. of Seebe, $A$. richardsoni were taken along Pocaterra Creek and along spring-fed streamlets emerging from benches and hillsides nearby. At lower elevations $(1220$ to $1830 \mathrm{~m})$ in the Kananaskis and Jumping Pound valleys the large runways characteristic of $A$. richardsoni were not observed. In over 12,000 trap-nights in the Jumping Pound area no specimens of this species were captured. We also failed to find sign, or capture specimens of $A$. richardsoni in frost-polygon formations at a higher elevation $(2843 \mathrm{~m}$ ) on Plateau Mountain (126 km south of Seebe, and east of the Kananaskis-Coleman Forestry Road, in the Highwood River drainage) (Fig. 1).

We have done most of our trapping for this species between mid-June and mid-September since at the appropriate elevations deep snow is present throughout the rest of the year. Our only winter trapping occurred in 1971, when ten traps were set, unsuccessfully, in known $A$. 
richardsoni habitat on Marmot Creek at $2200 \mathrm{~m}$ elevation on the night of 23 October. Snow depth at the time was 40 to $60 \mathrm{~cm}$.

The conclusions drawn from this exploratory trapping were that in the front ranges west of Calgary, Arvicola richardsoni could be expected to occur only at or near timberline (elevations of $2000-2200 \mathrm{~m}$ ) in close association with water (generally small spring-fed streams), and where the predominant vegetation was low alpine willow, mosses, forbs, and grasses. As the majority of these streams are spring-fed, the flow is relatively constant and the banks are not subject to a great deal of flooding or erosion during the snow-free months. Because of the limited distribution of this habitat, it appears that the general distribution pattern of $A$. richardsoni is highly discontinuous, and that the local distribution is linear and dendritic, following the pattern of favourable riparian habitat for short distances along headwater streams.

\subsection{General Description of Habitat in Areas Studied in 1972}

At Highwood Pass, streams flow northwards (headwaters of Pocaterra Creek) and southwards (headwaters of Storm Creek). The basin at the source of Pocaterra Creek slopes gently northwards and is rich in springs. From these, streamlets flow through beds of deep moss to join in a growing stream. As the basin drains northward it leads into a narrow and steeply sloping valley through which the stream becomes increasingly more boisterous as the gradient increases. The vegetation in the upper basin (Fig. 2B) consists of scattered small spruce, Picea engelmanni, larch, Larix lyalli and fir, Abies lasiocarpa, growing on mossy hummocks among semi-continuous stands of dwarf willow, Salix arctica, and Salix barratiana, 20 to $150 \mathrm{~cm}$ high. Trottie $\mathrm{r}(1972)$ refers to this community as the Salix barratiana association. Fir, spruce, and larcin form closed canopies on the higher and drier slopes surrounding the basin except where repeated snow avalanches have inhibited growth of woody vegetation.

The slope southward from Highwood Pass is drier, with fewer springs, less moss, and more grass. There was little sign of Arvicola richardsoni along the main course of Storm Creek in this area but well-developed runway systems ware found along spring-fed streamlets emerging beside the main stream.

On Plateau Mountain, Arvicola richardsoni was found in two springfed southward-sloping valleys at the headwaters of Wilkinson Creek $(2163$ to $2204 \mathrm{~m}$ ), and in a spring-fed northward-sloping valley tributary to Wilkinson Creek after its course turns northwestwards at Wilkinson Summit (elevation $2003 \mathrm{~m}$ ). At the higher sites, the streams run through 
narrow, twisting, grassy gulleys, entering fully developed timber along the lower reaches of the study area. Dwarf willow ranged from 40 to $200 \mathrm{~cm}$ in height along the stream banks (Fig. 2A). There was little moss at the two higher sites.

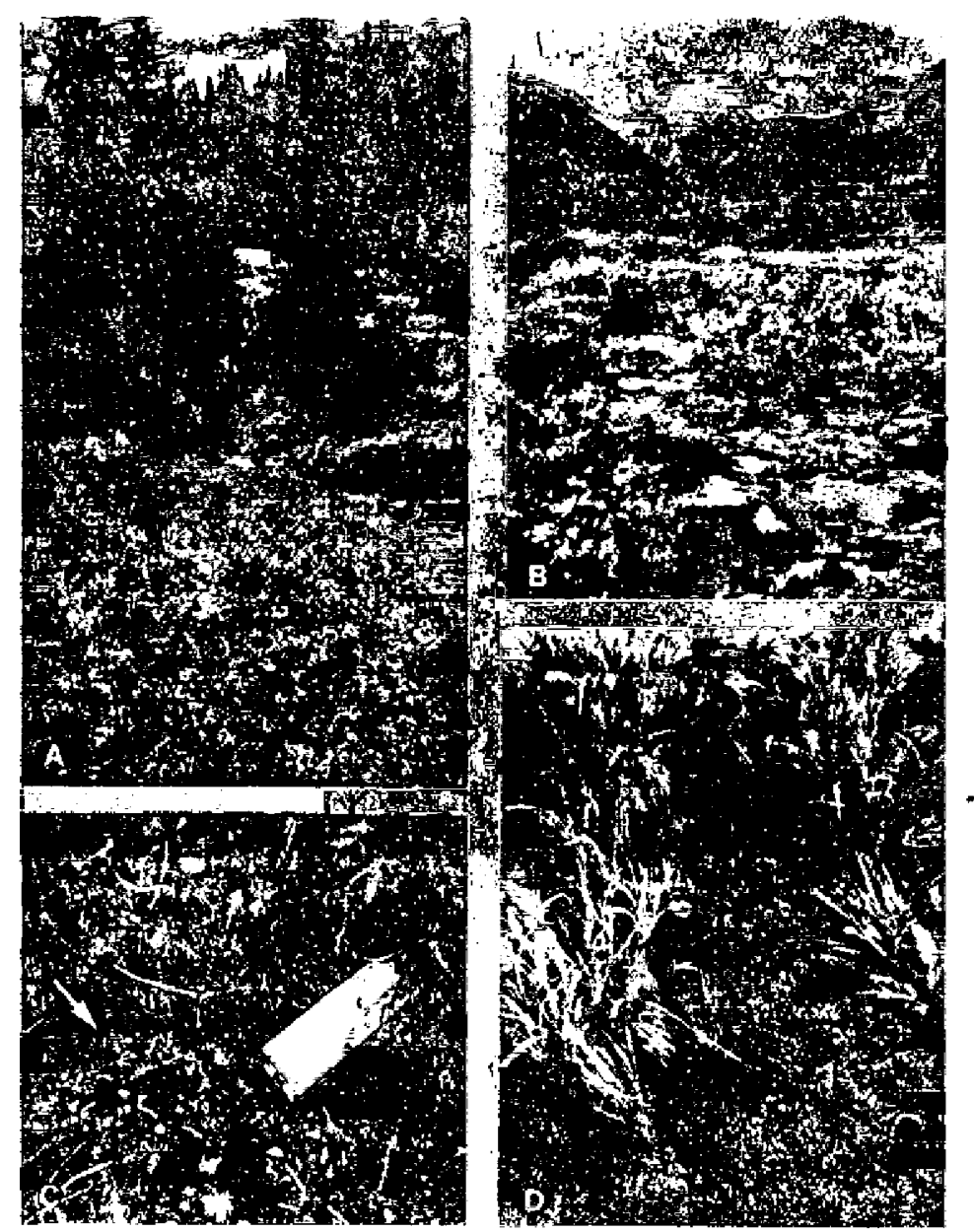

Fig. 2. Habitat occupied by Arvicola richardsoni.

A - View to the North along Pocaterra Creek at Highwood Pass. B - Wilkinson Creek headwaters with potential wintering habitat in left foreground. C - Runway with fresh cuttings of Senecio triangularis (arrow). D - Resting platform on stream bank.

The lower elevation site was trapped only in August and for one night to confirm evidence (runways and cuttings) of the presence of Arvicola richardsoni. Willow and moss were abundant, and at this elevation, willow reached $250 \mathrm{~cm}$ in height. 
In each location, the presence of $A$. richardsoni was indicated by well developed runway systems, resting sites, and burrow openings along the streams. These were typically found where dwarf willow provided some overhead cover. Runways are readily assignable to this species on the basis of size (width five to seven $\mathrm{cm}$, depth two to five $\mathrm{cm}$ ). Active runways are well worn (soil is often exposed on the runway floor) and free of litter and growing vegetation (Fig. 2C). In a typical runway system in the Pocaterra Creek headwaters at Highwood Pass, runways paralleled the stream for 32 meters and were well defined for three to four meters from the stream margin. Fainter runways and some freshly cut vegetation, apparently the work of Arvicola, were found as far as 11 meters from streamside. Runway systems had frequent openings to the margins of pools or rapidly running water. Along the stream banks resting platforms unconnected with runways were observed. These are small, well-packed clearings, often $T$ or $Y$ shaped (Fig. 2D). Large droppings (up to $3 \times 6 \mathrm{~mm}$ ) are occasionally found along the runways, but these are usually solitary. No large accumulations of feces are seen. We have observed that in captivity much defecation takes place in or near water (see also Skirrow, 1969) and suspect that in nature the majority of defecation and urination takes place in the streams. Burrow openings and runways frequently contain clusters of freshly cut forbs, willow twigs, or grasses (Fig. 2C).

The streams where signs of Arvicola richardsoni activity were found were generally quite small. A typical inhabited section of Pocaterra Creek at Highwood Pass (Fig. 2A) had a mean depth of $11 \mathrm{~cm}$, a mean width of $160 \mathrm{~cm}$, and a rate of flow $35 \mathrm{~cm} / \mathrm{second}$. The bottom was made up of angular rocks $10-100 \mathrm{~cm}$ in greatest dimension, with a mixture of coarse sand and fine gravels in the interstices.

Other small mammal species caught in our traps in 1972 in these habitats were Clethrionomys gapperi, Phenacomys intermedius, Microtus longicaudus, Zapus princeps, Peromyscus maniculatus, and Sorex palustris. Microtus pennsylvanicus was also caught in these habitats, in association with Arvicola richardsoni, on Plateau Mountain in the summer of 1973.1

\subsection{Trapping Effort and Catch}

The first 1972 expedition to Highwood Pass and Plateau Mountain took place in the first week in July. At this time growth of herbaceous vegetation was well underway, except in heavily shaded areas and on

\footnotetext{
1 Additional studies not treated in detail in this report.
} 
north-facing slopes where snow still remained. A large part of our effort was initially devoted to exploratory trapping, in order to define the habitats of the species more precisely. At Highwood Pass, 75 traps were set in areas which subsequently produced Arvicola richardsoni. These traps were available to the voles for a total of 2100 trap-hours (we have used strap-hours in preference to the less precise, but frequently used, strap-night*. A trap-hour represents one trap available for one hour). The total catch was five individuals $(0.0024$ voles/traphour). At Plateau Mountain 122 traps were set in occupied habitat and 2800 trap-hours produced five individuals ( 0.0018 voles/trap-hour).

In August, carefully controlled trapping sequences were undertaken at each locality. In these sequences trap sites were selected along subjectively comparable stretches of stream at each locality, utilizing the same criteria, by the senior author. These traps were initially set at the same time of day in each locality, and were checked at intervals of approximately 6 hours for 44 hours. At Highwood Pass 14 sets of five traps accumulated 3049 trap-hours. Fourteen individuals were captured (0.0046 voles/trap-hour). At Plateau Mountain, 19 sets of five traps accumulated 4221 hours and produced 28 individuals $(0.0066$ voles/trap-hour). These figures suggest that population density had approximately doubled at Highwood Pass and tripled at Plateau Mountain between the first week in July and the last week in August. The Wilkinson Summit site (2003 meters) at Plateau Mountain was trapped on the night of August 24 (25 traps in groups of five). Two water voles were captured $(0.0055$ voles/trap-hour).

The result of these standardized site-selection procedures indicated that identification of active runway systems was a reliable index of the presence of Arvicola richardsoni. The species was captured at 11 of 14 five-trap sets at Highwood Pass and 15 of the 19 sets at Plateau Mountain during the August study.

\subsection{Food}

Piles of freshly cut vegetation found in burrow entrances, and freshly cut plants and plant fragments found along runways are presumed to result from food gathering activity. Vegetation piles often include the entire above-ground parts of plants, suggesting that they represent collections of food gathered for subsequent consumption (Fig. 2C). Frag- ments found along runways may represent either discarded material, or food items dropped accidentally. As a first approximation of the diet we have included all of this plant material in our analysis, implying the belief that discarded plant parts may at least be residues left after preferred parts of the same plants have been consumed. 
In July 1972 six plant species were identified among such cuttings collected at Plateau Mountain [Trollius albiflorus (A. Gray) Rydb., Pedicularis groenlandica Retz., Castilleja miniata Dougl., Lonicera involucrata (Richards) Banks, Erigeron sp., and Thalictrum venulosum Trel.].

In August 1972, collections of cuttings were made along the Storm Creek section of our trap line at Highwood Pass and along the main trap line at Plateau Mountain (Fig. 1). Cuttings were sorted as to species, and counted. Fresh weight was taken for cuttings of each species in

Table 2

Plants cut by $A$. richardsoni along Storm Creek, Highwood Pass.

\begin{tabular}{lcc}
\multicolumn{1}{c}{ Species } & Segments & Per cent \\
\hline Unidentified grasses (2) & 71 & 58.2 \\
Salix sp. & 34 & 27.8 \\
Aster foliaceus & 9 & 7.4 \\
Unidentified forbs (2) & 6 & 4.9 \\
Pedicularis groenlandica & 2 & 1.7 \\
\hline
\end{tabular}

Table 3

Plants cut by A. richardsoni along Wilkinson Creek, Plateau Mt.

\begin{tabular}{lcrrr}
\hline \multicolumn{1}{c}{ Species } & Segments & Per cent & Grams & Per cent \\
\hline Senecio triangularis & 118 & 41.5 & 154 & 67.0 \\
Aster foliaceus & 74 & 26.0 & 21 & 9.1 \\
Unidentified grass & 19 & 6.7 & 2 & 0.9 \\
Salix sp. & 18 & 6.3 & 20 & 8.7 \\
Thalictrum occidentale & 12 & 4.2 & 2 & 0.9 \\
Allium schoenprasum & 10 & 3.5 & 3 & 5.7 \\
Pedicularis groenlandica & 10 & 3.5 & 5 & 1.7 \\
Ranunculus sp. & 8 & 2.8 & 2 & 0.9 \\
Viola orbiculata & 6 & 2.1 & 4 & 1.7 \\
Angelica dawsoni & 4 & 1.4 & 1 & 0.4 \\
Phileum alpinum & 1 & 0.4 & 1 & 0.4 \\
Castilleja occidentalis & 1 & 0.4 & 1 & 0.4 \\
Unidentified & 4 & 1.4 & & \\
\hline
\end{tabular}

the Plateau Mountain sample. The results of this examination are shown in Tables 2 and 3 . In each collection a single species appears to account for approximately $50 \%$ of the cuttings by number and/or by weight, and the four most common species account for $85 \%$ of the total. The species which are most common are not the same in the two collections. This suggests that although Arvicola richardsoni may feed on a variety of food plants, both herbaceous and woody, there is a tendency to 
concentrate on a few species, which need not the same in different localities or at different times. Grasses were numerically predominant in the sample of cuttings from Storm Creek, yet they accounted for only a small portion of the total weight of cuttings in the Plateau Mountain sample and it is our impression that grasses play a minor role in the normal diet of the water vole.

The occurrence of the plants identified as food items is not restricted to riparian biotopes in our study areas but extends into meadow and, in the case of some species, forest associations where no sign of Arvicola richardsoni activity was found and no specimens were captured. It thus appears that the restriction of $A$, richardsoni to streamside habitats is not a consequence of the distribution of food plants.

Table 4

Results of $2 \times 2$ contingency table test of association between successful trap sets and habitat features.

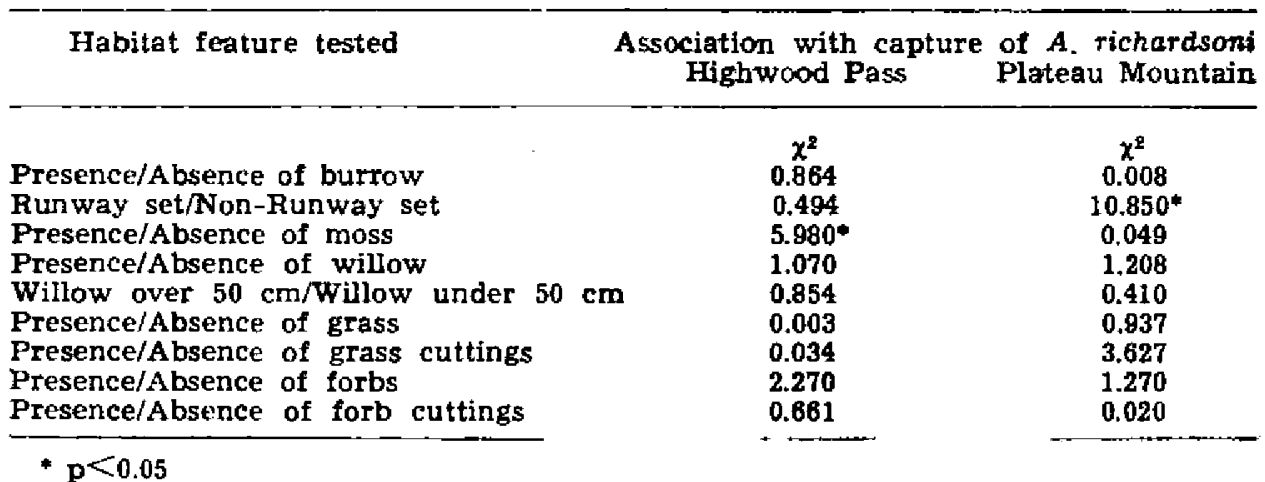

In an effort to further clarify habitat requirements, comparisons were made between those trap sets where water voles were captured and those where traps were unsuccessful. Such an evaluation is based on the assumption that animals are more likely to be trapped in preferred habitat (Table 4).

The tests for association indicate that traps are likely to be most successful if set in a runway. They also suggest that within the habitat there is no significant association between the probability of capture of Arvicola richardsoni and most of the habitat features which we noted.

\subsection{Categorization of Animals}

We have assigned individual water voles to categories believed to represent distinct components of the population. At this stage in our 
study of $A$. richardsoni these assignments are unavoidably tentative, but still useful. Our procedure has been to indicate the apparent level of sexual activity on a plot of body weight against body length (Fig. 4). Males were classified as active (testes scrotal) or inactive (testes abdominal). Females were classified as inactive (nipples small, pubic symphysis closed, vagina imperforate or perforate), possibly active (nipples moderate and vagina perforate or imperforate, or, if the nipples were small, the pubic symphysis open and the vagina perforate), and active (nipples large, or if moderate, showing a hair-free area around

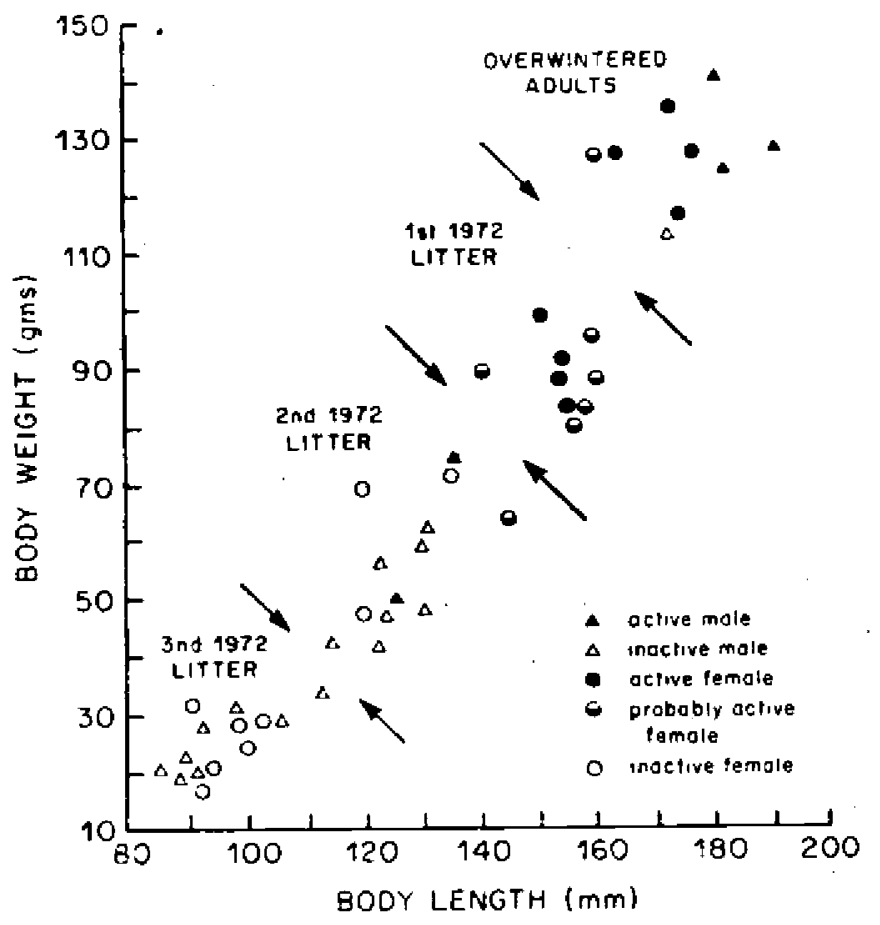

Fig. 3. Relationships of weight, length, and reproductive status used to categorize Arvicola richardsoni caught in August 1972,

them, pubic symphysis open or closed, vagina perforate). The two females which appeared to be pregnant were included in the active category on the basis of the criteria listed.

All individuals captured in July are assumed to have overwintered. Excepting one female and one male, all July animals were categorized as sexually active.

On the basis of Fig. 3, August animals were assigned to four categories: overwintered adults weighing 110 grams or more with body lengths of $162 \mathrm{~mm}$ or greater; animals of the first litter of the 1972 
breeding season weighing 80 to $96 \mathrm{~g}$, with body lengths of 140 to 160 min (all were females, three classified as sexually active and five possibly active); animals of the second litter of the 1972 season, weighing from 42 to $75 \mathrm{~g}$, with body lengths from 114 to $145 \mathrm{~nm}$ (seven of nine males had abdominal testes, and three females were sexually inactive and one was possibly active by our criteria); and animals of the third litter, weighing from 19 to $35 \mathrm{~g}$ with body lengths of 90 to $112 \mathrm{~mm}$ ( $1+$ individuals, none sexually active).

\subsection{Activity Rhythms}

The 44 hour trapping sequences conducted in August provide a basis for analysis of the temporal distribution of captures. These data (Fig. 4)

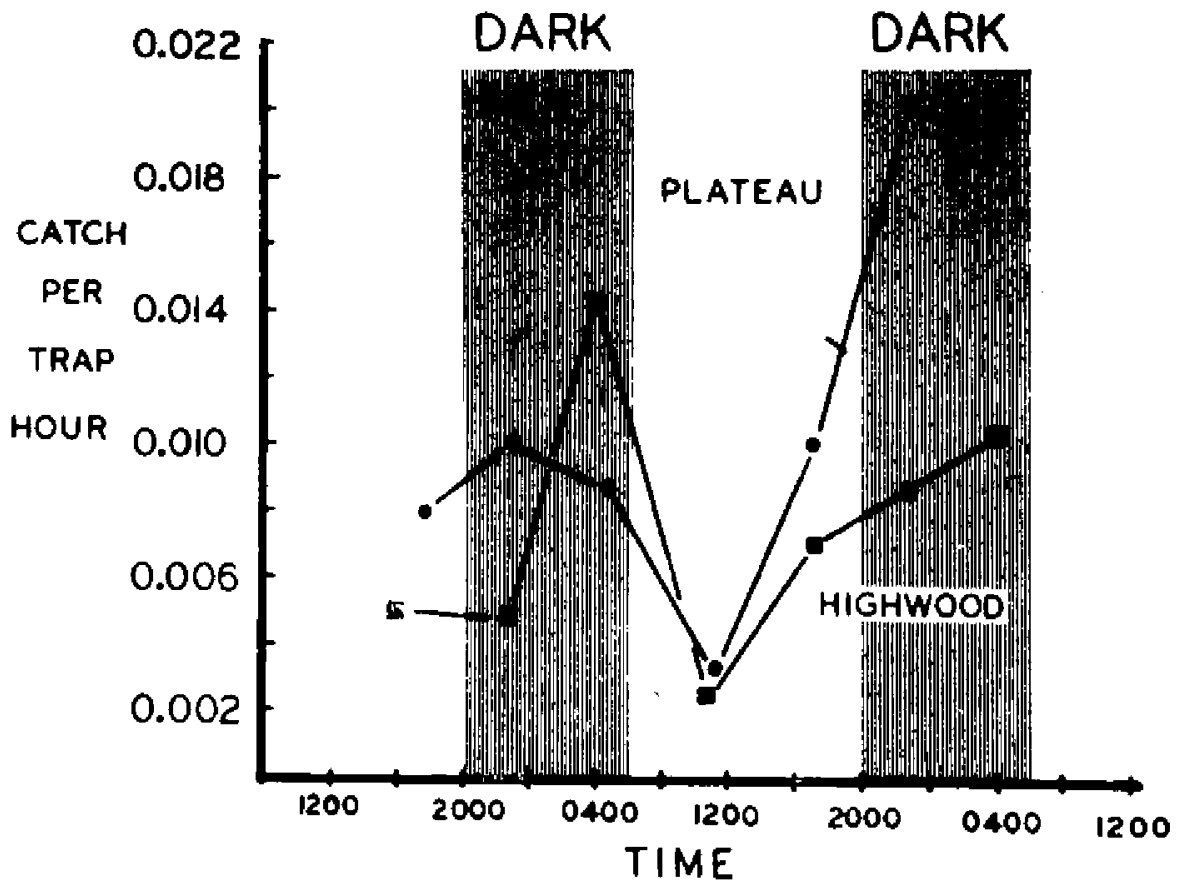

Fig. 4. Diel activity rhythm of Arvicola richardsoni as recorded in 44-hour trapping sequences in August 1972. Values are plotted at mid points of catch periods of approximately six hours duration.

suggest that activity is lowest between dawn and mid-day, rising during the afternoon, and reaching a peak during the hours of darkness, probably after midnight. As we moved through the habitat setting traps or recording habitat data during the afternoon hours, we occasionally saw animals travelling along runways. 
3.7. Behaviour

Released animals frequently leaped into the water rather than choosing to escape on land. They were good swimmers and could move upstream against the current. Most swimming was on the surface, but in quiet pools we occasionally saw animals swimming under water.

Our August data permit a preliminary analysis of movement patterns, based on the maximum intercapture distance (MID). Eighteen individuals were captured two or more times, and data for 17 of these individuals were suitable for tabulation (Table 5). Each of the 17 individuals were recorded in at least two five-trap clusters. Since the five traps in each cluster had been distributed to cover the extent of an apparently discrete runway system, this indicates that each animal uses more than one set of streamside runways.

Table 5

Maximum intercapture distance 1.

\begin{tabular}{lcccc}
\hline Category $^{2}$ & Sex & No. individuals & Distance, $\bar{X}$ & Range, $\mathrm{m}$ \\
\hline OA & M & 2 & 167.0 & $123-211$ \\
OA & F & 5 & 38.1 & $21-51$ \\
$72-1$ & F & 4 & 22.1 & $3-56$ \\
$72-2$ & M & 1 & $(284.0)$ & - \\
$72-3$ & M & 3 & 8.3 & $5-15$ \\
$72-3$ & F & 2 & 17.5 & $17-18$ \\
\hline
\end{tabular}

1 Maximum intercapture distance is defined as the greatest distance separating any pair of captures of an individual

$2 \mathrm{OA}=$ Overwintered adult, $72-1=$ First 1972 litter, $72-2=$ Second 1972 litter, $72-3=$ Third 1972 litter.

When the movement data are examined with respect to the population category to which the individual was assigned, it appears that in August newly weaned animals (the third litter of the season) showed the lowest vagility. Overwintered adult males appeared to move greater distances than did overwintered adult females. The most vagile of the two adult males had scrotal testes in July, but had abdominal testes in August. The individual moving the greatest distance was a male assigned to the second litter of the season, with abdominal testes.

\subsection{Dispersion, Density, and Population Composition}

Our impression was that burrows, runway systems, and other signs of water vole activity indicated an aggregated pattern of occurrence within occupied habitat along the streams (Fig. 5). At each locality there appeared to be only a single overwintered adult male present in 
the study area. Two overwintered adult females were recorded along Pocaterra Creek and three were caught along Wilkinson Creek. There was overlap between the observed ranges of the male and one of the females in each case, but no overlap between the ranges of overwintered

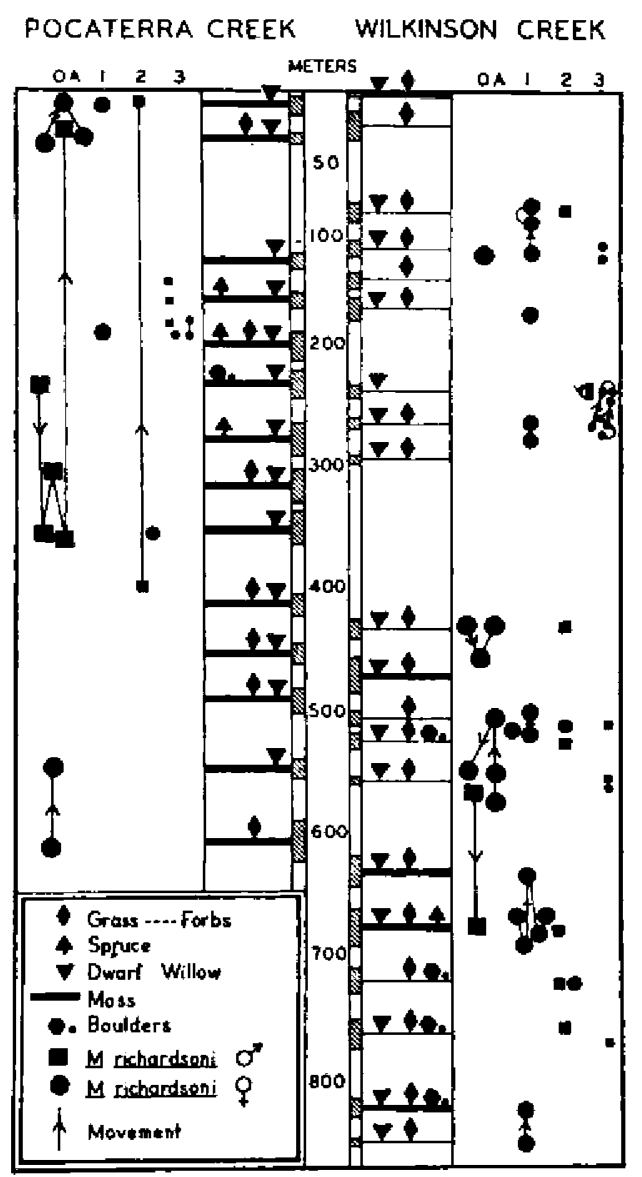

Fig. 5. Dispersion and movement of Arvicola richardsoni along Pocaterra Creek and Wilkinson Creek in August 1972.

Distance ajong trap lines is indicated on the center scale. Hatched areas indicate the extent of live-trap clusters, each set along the extent of a discrete runway concentration. Dominant vegetation and associated habitat features are indicated for each cluster of traps. Voles are categorized as overwintered adult (OA), or members of the first (1), second (2), or third (3), litters of the 1972 season. Sex, capture sites, and extent and direction of observed movement are indicated.

adult females. On Pocaterra Creek there was no overlap between observed ranges of sexually active or probably active females. On Wilkinson Creek the range of one probably active female assigned to the first 1972 litter was included within the range of a definitely active 
female, and both were caught at the same station. These data suggest that established breeding males have large ranges, exclusive of other overwintered adult males, and that established breeding females have smaller ranges, exclusive of other overwintered adult females but overlapped by the range of an established adult male.

In calculating density we have concentrated on the areas systematically trapped in August, and made the assumption that activity was restricted to a zone extending five meters on either side of the stream. Estimates of numbers of individuals, and of biomass, reflect the number of animals actually captured and are thus minimal figures (Table 6). Estimates of the number and densities of overwintering adults include

Table 6

Estimates of density and biomass of Arvicola richardsohi on main traplines.

\begin{tabular}{|c|c|c|}
\hline$!$ & $\begin{array}{l}\text { Highwood Pass, } \\
\text { Pocaterra Creek -p }\end{array}$ & $\begin{array}{l}\text { Plateau Mountain } \\
\text { Wilkinson Creek }\end{array}$ \\
\hline $\begin{array}{l}\text { Area sampled, hectares } \\
\text { Total individuals captured in August } \\
\text { Indiv./hectare in August } \\
\text { Adults present in August } \\
\text { August, Adults/hectare } \\
\text { Young of the year present in August } \\
\text { August, Young/hectare } \\
\text { Total, August biomass, gm } \\
\text { Total, August biomass/hectare, gm } \\
\text { Aduit, August biomass/hectare, gm ... } \\
\text { Young, August biomass/hectare, gm } \\
\text { Overwintering Adults, July } \\
\text { Av. wt. of overwintering aduIts, gm } \\
\text { Overwintering adults biomass/hectare, gm } \\
\text { No. of overwintering adults/hectare }\end{array}$ & $\begin{array}{cc}- & 0.6235 \\
11 & 17.64 \\
3 \\
9.6 \\
8 \\
12.8 \\
747 \\
1198 \\
574 \\
624 \\
6 \\
128 \\
1167 \\
9.6\end{array}$ & $\begin{array}{c}0.9620 \\
28 \\
32.48 \\
4 \\
8.1 \\
24 \\
27.8 \\
1780 \\
2065 \\
604 \\
1461 \\
7 \\
133 \\
1075 \\
\text { B..1 }\end{array}$ \\
\hline
\end{tabular}

all animals of the appropriate size captured in either the July and/or August censuses.

Distribution of our July and August animals by sex and body length is shown in Fig. 6. Among overwintered adults it appears that the sex ratio is close to equality. As mentioned previously all animals assumed to belong to the first litter of the 1972 breeding season are females. The probability of drawing a sample of eight females from a population in which the sex ratio is equal is only 0.004 . It therefore appears that unless our classification has been affected by differential growth rates, a biased sex ratio exists among the members of the first Iitter present at the time of our study. Among adults and animals assumed to belong to the second and third litters there were no significant departures from a $1: 1$ sex ratio. 
The July sample appears to consist exclusively of adults that have survived at least one winter. In August, at Highwood Pass, the animals categorized as young of the year made up $66^{\%} \%(10 / 15)$ of the total, while at Plateau Mountain they accounted for $83 \%$ (25/30). A $2 \times 2$ contingency test for homogeneity gives a non-significant chi-squared value for a comparison of the total samples from the two areas and therefore the apparent difference in the reproductive rate cannot be considered to be significant. The ratios of the number of young per

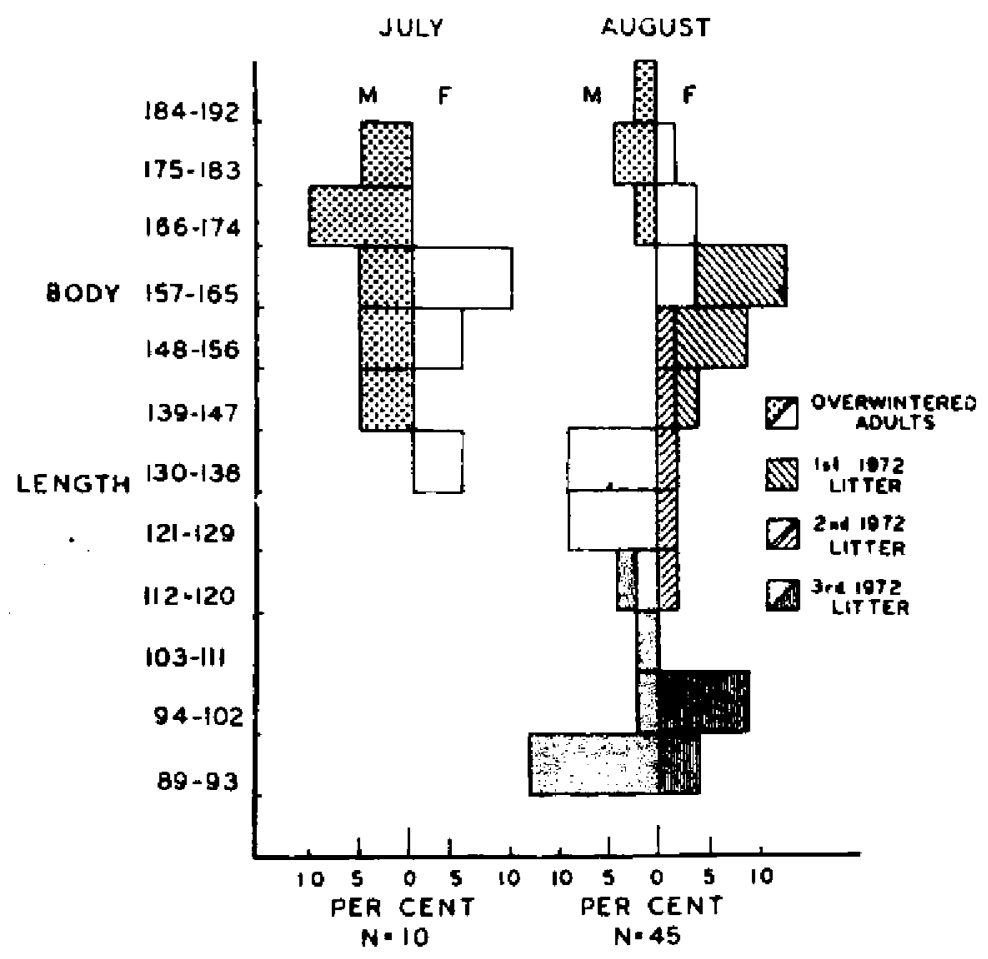

Fig. 6. Composition of Arvicola richardsoni populations on Pocaterra Creek and Wilkinson Creek in 1972 ( $\mathrm{July}$ and August samples pooled).

adult, and of young per overwintered female observed for the standardized trap lines are $3 / 1$ and $4.5 / 1$ on Pocaterra Creek and considerably higher (5.5/1 and 7.3/1) on Wilkinson Creek, but in neither. ratio does there appear to be a statistically significant difference between the two areas.

\subsection{Reproduction}

Our July sample shows no evidence of recruitment or reproductive activity during the winter of $1971-72$. In the first week in July no 
litters had emerged, but most members of the populations were in reproductive condition. Testes were descended in five of the six males caught. One female was visibly pregnant and two others showed hairfree areas around the nipples.

Of four overwintered males captured in August, three were active and one (which had been caught in July and recorded as active) had abdominal testes. Five overwintered adult females were active in August, while one was categorized as possibly active.

There is strong evidence that females belonging to the first litter of the summer were coming into reproductive condition in August of the same year. Four of nine females in the $70-100 \mathrm{~g}$ body weight group were classified as reproductively active, and the other five were classified as probably active, as was one female weighing only $6 \pm \mathrm{g}$. All females with a body length of over $139 \mathrm{~mm}$ were active or probably active as defined above. An $80 \mathrm{~g}, 130 \mathrm{~mm}$ female which died in a trap on Wilkinson Creek on August 4th, 1973 was dissected. The right horn of the uterus showed no scars or implantation sites and there were no corpora lutea in the right ovary. Four $19 \mathrm{~mm}$ embryos and one smaller (resorbing) embryo were found in the left uterine horn and there were five large corpora lutea in the left ovary. In the previous year's sample this female would have been assigned to the first litter of the season.

A $104 \mathrm{~g}, 163 \mathrm{~mm}$ female, which also died in a trap at Wilkinson Creek in the first week of August 1973, was pregnant (seven $9 \mathrm{~mm}$ embryos) and the uterus showed seven scars from an earlier pregnancy. There were seven active corpora lutea and seven corpora albicantia in the ovaries.

An overwintered adult female accidentally killed at Highwood Pass in the August 1972 census was also dissected. The vagina was perforate, the nipples were enlarged with a hair-free area, and the symphysis was partly open. Each ovary contained three corpora lutea. The uterine horns were swollen and two scars were present in each. This condition suggests the beginning of a post-lactational estrus after having produced a single litter without a post-partum mating. This individual had previously been caught in July and had then been classified as sexually inactive.

\subsection{Biochemical Variation}

In the absence of progeny data, our interpretation of observed starch gel patterns is inferred on the basis of observations on other microtines, Peromyscus polionotus, and Mus musculus (e.g., Gaines \& $\mathrm{Krebs}$, 1971; Selander et al, 1971; Roderick et al. 1971) and must be considered provisional. 
Typical patterns produced by electrophoresis of plasma and red cell lysates, and the designations we have applied, are illustrated in Fig. 7 and nomenclature is indicated in Table 7. In the descriptions which follow, migration is anodal unless otherwise specified and migration distances are measured from the origin to the trailing edge of the band described.

Transferrin preparations were read for 49 individuals. In each, appropriately staining bands occurred at distances of 47 and $52 \mathrm{~mm}$ from the origin. Thirty-eight individuals were scored for hemoglobin and for glucosephosphate isomerase. A single band $7 \mathrm{~mm}$ wide was ob-

PLASMA

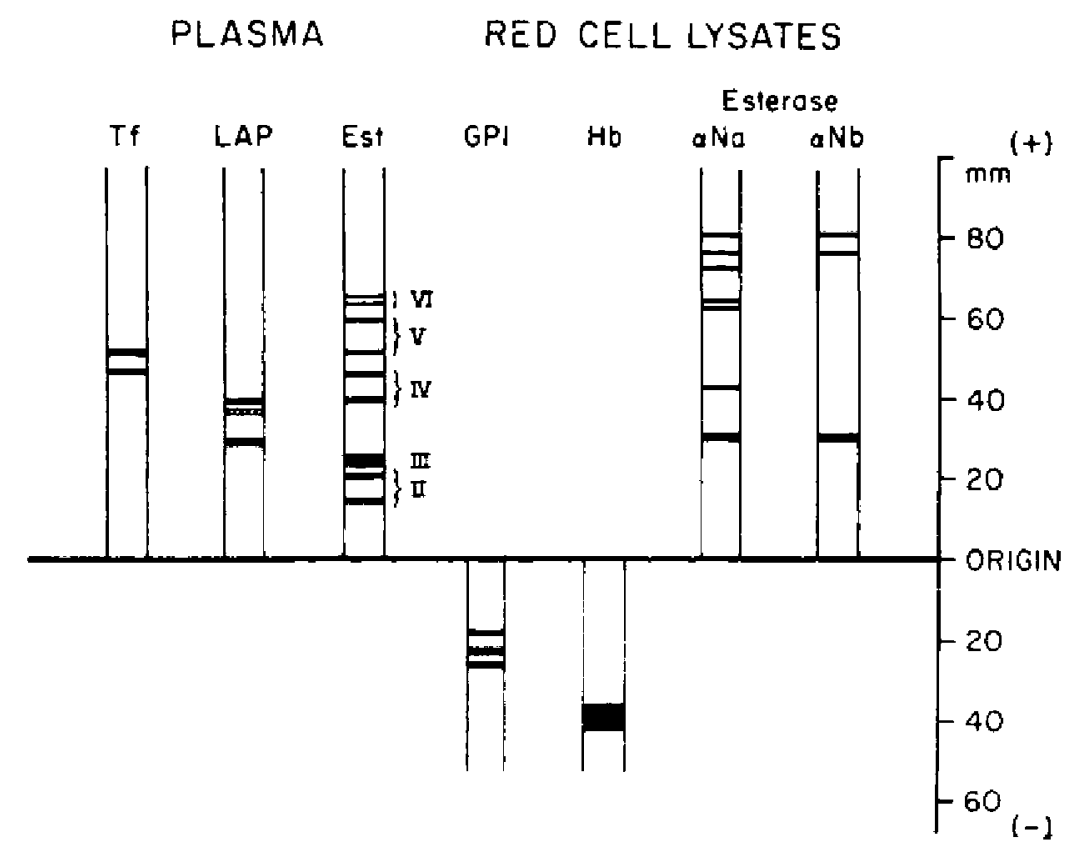

RED CELL LYSATES

1

Fig. 7. Patterns observed in starch gel electrophoresis of Arvicola richardsoni plasma and hemolysates.

The patterns shown are generalizations and do not necessarily represent any individual sample. Only invariant zones are represented for red cell esterases. The intermediate (lighter) band shown for leucine amino peptidase was observnd only in young animals (see text).

served $35 \mathrm{~mm}$ cathodal to the origin in all hemoglobin preparations. In all glucosephosphate isomerase preparations cathodally migrating bands were located at $17 \mathrm{~mm}, 21 \mathrm{~mm}$, and $25 \mathrm{~mm}$. We assume that transferrin, hemoglobin and glucosephosphate isomerase patterns are each controlled by one locus. Since our preparations did not reveal any variation at these three loci it is assumed that all are monomorphic in the populations studied. 
Seven other invariant loci appear to be identifiable in our material. In all plasma esterase preparations (49 individuals represented) a heavily staining band $2-3 \mathrm{~mm}$ wide occurred at $24 \mathrm{~mm}$. The remaining six invariant loci were identified in hemolysate preparations (49 individuals represented). In both $\alpha$-naphthyl acetate and $\alpha$-naphthyl butyrate preparations single bands were universally present between 29 and $31 \mathrm{~mm}$, between 73 and $81 \mathrm{~mm}$, and between 77 and $86 \mathrm{~mm}$. On $\alpha$-naphthyl acetate only, a single band was visible for all samples at $43 \mathrm{~mm}$ and another between 68 and $76 \mathrm{~mm}$ (where there is overlap in

Table 7

Nomenclature and descriptions for four polymorphic loci.

\begin{tabular}{|c|c|c|c|}
\hline \multirow[b]{2}{*}{ Locus } & \multirow{2}{*}{$\begin{array}{l}\text { Presumed } \\
\text { alleles }\end{array}$} & \multicolumn{2}{|c|}{ Phenotypes } \\
\hline & & Homozygotes & Heterozygotes \\
\hline Leucine amino peptidase & $\begin{array}{l}\text { Lap-1a } \\
\text { Lap-1b }\end{array}$ & $\begin{array}{l}\text { single band at } 30 \mathrm{~mm} \\
\text { single band at } 40 \mathrm{~mm}\end{array}$ & both bands present \\
\hline Plasma esterase 2 & $\begin{array}{l}P E s-2^{a} \\
P E s-2 b\end{array}$ & $\begin{array}{l}\text { single band at } 15 \mathrm{~mm} \\
\text { single band at } 21 \mathrm{~mm}\end{array}$ & both bands present \\
\hline Plasma esterase 4 & PEs-4a & $\begin{array}{l}\text { bands at } 30 \mathrm{~mm} \text { and } \\
46 \mathrm{~mm} \text {, but the } \\
30 \mathrm{~mm} \text { band more } \\
\text { intense } \\
\text { bands at } 30 \mathrm{~mm} \text { and } \\
46 \mathrm{~mm} \text {, but the } \\
46 \mathrm{~mm} \text { band more } \\
\text { intense }\end{array}$ & $\begin{array}{l}\text { both bands equally } \\
\text { intense }\end{array}$ \\
\hline Plasma esterase 5 & $\begin{array}{l}P E s-5 a \\
P E s-5 \mathrm{~b}\end{array}$ & $\begin{array}{l}\text { single band at } 52 \mathrm{~mm} \\
\text { single band at } 60 \mathrm{~mm}\end{array}$ & both bands present \\
\hline
\end{tabular}

the measured distances indicated, variation in migration and/or shrinkage between gels is reflected). Also, on $\alpha$-naphthyl acetate only, an invariant zone with paired bands, $1 \mathrm{~mm}$ apart, was present between 63 and $70 \mathrm{~mm}$. In total, therefore, we have inferred that a minimum of ten invariant loci can be recognized.

Variation was observed in leucine amino peptidase (LAP) preparations, and in several regions in plasma and red-cell esterase material. In the majority of cases we were unable to score all individuals, and interpretation of esterase variation was generally difficult.

Leucine amino peptidase preparation were classified for 48 individuals. Bands were observed at 30,37 and $40 \mathrm{~mm}$. Variant patterns initially recognized were (1) a single band at $30 \mathrm{~mm}$, (2) a single band at $40 \mathrm{~mm}$, (3) bands at both $30 \mathrm{~mm}$ and $40 \mathrm{~mm}$, and (4) the $30 \mathrm{~mm}$ band and a second, less intense band, at $37 \mathrm{~mm}$. In eight of the 10 cases where (4) occurred, the individual was a non-adult male. The 
remaining two individuals were very small and had been identified as females (third litter of 1972). On the postulate that these may possibly have been misidentified as to sex, and that the expression of the double-banded (presumably heterozygous) phenotype may be modified in some way in young animals (presumably males according to this hypothesis), variants (3) and (4) are considered identical and the system is assumed to represent a pair of co-dominant alleles.

Six of the seven zones defined in plasma esterase preparations showed variation. Proximally $(0-15 \mathrm{~mm})$ and distally $(70-85 \mathrm{~mm})$ definition deteriorated, and although variation was apparent, no attempt at analysis was made. In each of zones $I I, I V, V$ and $V I$ (see Fig. 7) it appeared that a pair of alleles was segregating at a single locus. Variants observed were as follows:

Zone II (15-23 mm); a single band at $15 \mathrm{~mm}$, a single band at $21 \mathrm{~mm}$, or bands at both $15 \mathrm{~mm}$ and $21 \mathrm{~mm}$.

Zone IV ( $30-50 \mathrm{~mm}$ ); two bands (40 and $46 \mathrm{~mm}$ ) present in all cases but either both bands of equal intensity, the $40 \mathrm{~mm}$ band more intense, or the $46 \mathrm{~mm}$ band more intense.

Zone $V(50-62 \mathrm{~mm})$; a single band at $52 \mathrm{~mm}$, a single band at $60 \mathrm{~mm}$, or both bands present. When only the $52 \mathrm{~mm}$ band was present there was commonly a trailing blur behind it.

Zone VI (64-70 mm); bands at $64 \mathrm{~mm}, 66 \mathrm{~mm}$, or both. The $64 \mathrm{~mm}$ band was often diffuse and we found it difficult to type individuals at this presumed locus.

Analysis of variants in the esterases in hemolysate preparations proved particularly difficult. It appeared that some bands stained with both $\alpha$-naphthyl acetate and $\alpha$-naphthyl butyrate, while others did not. Those which were at a given distance from the origin and stained with both preparations were assumed to be homologous.

A variant zone was identified on $u$-naphthyl gels in the region between 60 and $66 \mathrm{~mm}$, located proximal to the paired invariant bands observed in the $63-70 \mathrm{~mm}$ region on a-naphthyl acetate. On both acetate and butyrate gels thete was a variable region between 15 and $25 \mathrm{~mm}$. A great deal of effort was devoted to the interpretation of these two variable zones, but we were unable to arrive at a satisfactory conclusion for either in the absence of progeny testing.

Our best estimate at this point is that nine polymorphic loci and ten monomorphic loci have been identified. For the four polymorphic loci where we felt sufficiently confident of our interpretation we have ascribed genetic terminology as shown in Table 7, and we have summarized variation in Tables 8 and 9 . Among these four loci the proportion of individuals heterozygous ranged from 15.5 to $67.4^{\mathrm{B}} \%$ in the pooled sample. It appears that the Highwood Pass population may be 
Table 8

Allelic and heterozygote frequencies in Arvicola richardsoni.

\begin{tabular}{|c|c|c|c|c|c|c|c|c|c|c|c|}
\hline & \multirow[b]{2}{*}{ Locus } & \multicolumn{4}{|c|}{ Pooled Sample } & \multicolumn{3}{|c|}{ Highwood Pass } & \multicolumn{3}{|c|}{ Plateau Mt. } \\
\hline & & $\mathbf{N}$ & $\begin{array}{l}\text { alle } \\
\text { freque } \\
\text { a }\end{array}$ & $\begin{array}{l}\text { lic } \\
\text { ncies } \\
b\end{array}$ & $\begin{array}{l}\text { \% hetero- } \\
\text { zygotes }\end{array}$ & $\mathbf{N}$ & $\begin{array}{l}\text { frequency of } \\
\text { more common } \\
\text { allele }\end{array}$ & $\begin{array}{c}\text { 莒 hetero- } \\
\text { zygotes }\end{array}$ & $\mathbf{N}$ & $\begin{array}{l}\text { frequency of } \\
\text { more common } \\
\text { allele }\end{array}$ & $\begin{array}{l}\text { o hetero- } \\
\text { zygotes }\end{array}$ \\
\hline Leucine & amino peptidase & 48 & 0.666 & 0.333 & 58.3 & 15 & 0.733 & 40.0 & 33 & 0.636 & 66.6 \\
\hline Plasma & esterase 2 & 39 & 0.077 & 0.923 & 15.5 & 16 & 1.00 & - & 23 & 0.869 & 26.0 \\
\hline Plasma & esterase 4 & 43 & 0.453 & 0.547 & 67.4 & 12 & 0.583 & 83.3 & 31 & 0.533 & 61.3 \\
\hline Plasma & esterase 5 & 34 & 0.765 & 0.235 & 35.2 & 15 & 0.734 & 53.4 & 19 & 0.779 & 21.0 \\
\hline
\end{tabular}

Table 9

Conformity of genotypic frequencies to Hardy-Weinberg equilibrium proportions in Arvicola richardsoni at Plateau Mountain.

\begin{tabular}{|c|c|c|c|c|c|c|c|c|c|c|c|c|c|c|c|}
\hline \multirow{2}{*}{ Locus } & \multicolumn{6}{|c|}{ Pooled data } & \multicolumn{5}{|c|}{$\begin{array}{l}\text { Observed } \\
\text { in overwintered adults }\end{array}$} & \multicolumn{3}{|c|}{1972 genera:ion } & \multirow[b]{2}{*}{$x^{2}$} \\
\hline & $a a$ & $a b$ & $b b$ & $f_{s}$ & $f_{0}$ & $x^{2}$ & $a a$ & $a b$ & $b b$ & $f_{a}$ & $f_{b}$ & $a a$ & $a b$ & $b b$ & \\
\hline $\begin{array}{l}\text { LAP-1 } \\
P E S-2 \\
P E S-4 \\
P E S-5\end{array}$ & $\begin{array}{c}10 / 13.3 \\
0 / 0.4 \\
5 / 6.8 \\
13 / 11.8\end{array}$ & $\begin{array}{c}22 / 15.3 \\
6 / 5.2 \\
19 / 15.4 \\
4 / 6.3\end{array}$ & $\begin{array}{c}1 / 4.4 \\
17 / 17.4 \\
7 / 8.8 \\
2.80\end{array}$ & $\begin{array}{l}0.636 \\
0.130 \\
0.468 \\
0.789\end{array}$ & $\begin{array}{l}0.364 \\
0.870 \\
0.532 \\
0.211\end{array}$ & $\begin{array}{l}1.37 \\
0.04 \\
1.69 \\
0.29\end{array}$ & $\frac{3}{3}$ & $\begin{array}{l}6 \\
3 \\
2 \\
\end{array}$ & $\begin{array}{l}73 \\
1 \\
\end{array}$ & $\begin{array}{l}0.667 \\
0.250 \\
0.667\end{array}$ & $\begin{array}{l}0.333 \\
0.750 \\
0.333 \\
0 .\end{array}$ & $\begin{array}{l}7 / 10.7 \\
0 / 1.1 \\
2 / 11.1\end{array}$ & $\begin{array}{c}16 / 10.7 \\
3 / 6.4 \\
17 / 111.1 \\
4 / 0\end{array}$ & $\begin{array}{r}1 / 2.7 \\
14 / 9.6 \\
6 / 2.8\end{array}$ & 4.12* \\
\hline
\end{tabular}

* $p=<0.05$ observed/expected $\chi^{2}$ 
fixed for the $2^{b}$ allele at the plasma esterase 2 locus. The same allele had a frequency of $87 \%$ in our Plateau Mountain sample. The frequency of heterozygotes was, however, greater at Highwood Pass than at Plateau Mountain at two of the remaining three loci. At both localities it was the same allele which predominated at a given locus.

On the basis of the four loci at which we feel reasonably confident of our scoring, and the fourteen individuals from both areas on which we were able to score all of these loci, the average proportion of Ioci heterozygous per individual is 0.122 . Rogers (as cited in $\mathrm{Johns}$ on \& Selande $r, 1971$ ) has developed an index of similarity $(S)$ :

$$
S=1-\frac{1}{L} \sum_{i=1}^{L}\left[\frac{1}{2} \sum_{j=1}^{A_{i}}\left(P_{i j x}-P_{i j y}\right)^{2}\right] \frac{1}{2}
$$

where $L$ is the number of loci, $A_{i}$ is the number of alleles at the $i^{\text {th }}$ locus, and $P_{i j x}$ and $P_{i j y}$ are the frequencies of the $j^{\text {th }}$ allele at the $i^{\text {th }}$ locus in populations $x$ and $y$ respectively. Despite the very small number of loci (14) and of individuals for which all loci were scored (eleven from Plateau Mountain and three from Highwood Pass), we have calculated this index for the two populations. The value obtained $(S=$ $0.9716)$ is similar to values obtained for paired conspecific populations in the genus Dipodomys by J ohns on \& Selander (1971).

\section{DISCUSSION}

Our intent in this study was comparison of Arvicola richardsoni with better known species as regards population structure and adaptive strategy. Ideally a comparison should be made with one or more widely distributed species which each occupy a similar niche, are ecologically and biochemically well studied, and co-occur with $A$. richardsoni. Unfortunately no such comparison is possible at present. We shall concentrate on (1) the water vole of Europe, Arvicola terrestris, (2) North American rodents which co-occur with $A$. richardsoni in the riparian habitats at timberline in our region (Microtus longicaudus, Microtus pennsyivanicus, Clethrionomys gapperi, and Peromyscus maniculatus), and (3) species for which patterns of biochemical variation are relatively well demonstrated (Mus musculus, Peromyscus polionotus, Dipodomys sp. and the Thomomys talpoides complex).

\subsection{Habitat Speeialtzation and Geographic Distribution}

In the light of the similarities between Arvicola terrestris and Arvicola richardson: in size and behaviour the contrasts in geographic di- 
stribution and habitat specialization in the two water voles are especially striking. The geographic range of $A$. richardsoni is quite restricted. Our study was done in the Rocky Mountain front ranges, at the eastern limits of the Canadian distribution. The species has been recorded to the north in the Rockies only to Mount Robson (approximately $53^{\circ}$ North latitude). In British Columbia, it occurs in the Selkirk, Cascade, and coast ranges, but only to about $51^{\circ}$ North in the latter (Cow a n \& Guiget, 1960). Southwards in the Rockies it is found through Montana and Wyoming to south central Utah (Rasmussen \& Chamberlain, 1959), but is not known from Colorado. According to $\mathrm{H}$ of $\mathrm{fm}$ an \& Jones $(1970) A$. richardsoni has been able to colonize only two of the several isolated ranges in the northern great plains (Bighorn and Big Belt Mountains). Southwards in the Cascades it reaches Crater Lake in Oregon (B a iley, 1936). There is riparian timberline habitat in abundance both north and south of the $A$. richardsoni range. On the basis of its distribution, this species appears unable to readily transgress lowland barriers to reach suitable subalpine habitat.

In contrast to the limited geographical and altitudinal distribution of $A$. richardsoni, $A$. terrestris ranks with the most widely distributed of rodent species. It occurs from the British Isles eastward to the drainage of the easternmost tributaries of the Lena River in Siberia, and from the Arctic Ocean to Israel, the shores of the Black Sea, ${ }^{-}$Greece and Spain (Ognev, 1950; Ellerman \& Morrison-Scott, 1951 and W a $1 \mathrm{ke} \mathrm{r}, 1964)$.

The geographical ranges of the North American rodents we have found co-occurring in the habitat with $A$. richardsoni in our study area are all very extensive. Peromyscus maniculatus has the greatest range of any North American rodent. The ranges of Microtus pennsylvanicus and Clethrionomys gapperi are also exceptionally large. Microtus longicaudus occurs only in the mountainous regions of the west but occupies a much more extensive geographic area than does Arvicola richardsoni.

All of the above species, including Arvicola terrestris, also occupy a much more extensive altitudinal range than does $A$. richardsoni. Although much of the area where $A$. tererstris occurs is lowland, Og n e v (1950) mentions its presence along streamsides and lake margins in subalpine meadows, and $\mathrm{Zejda} \& \mathrm{Zapletal}$ (1969) refre to desoriptions of its distribution along streams in ssubmontane and montane regions\&. We can assume, therefore, that $A$. richardsoni occupies a habitat, and an ecological niche, which is in some sense a subdivision of the broader habitat and niche amplitudes of the above mentioned species. The most logical components of the environment for examina- 
tion in attempting to define the limiting factors for $A$. richardsoni are microclimate and food.

Mean annual temperatures at the summit of Highwood Pass range near $-2^{\circ} \mathrm{C}$ (B a ig, 1972). Monthly mean temperatures are above $1^{\circ} \mathrm{C}$ only from June through August $\left(4.2,9.7,7.1\right.$, and $4.2^{\circ} \mathrm{C}$ for these Trottier (1972). In our experience winter snow cover is usually established by mid-September and lasts until mid-June.

There is a high degree of consistency in descriptions of $A$. richardsoni habitat. Cow an \& Guiget (1960) note the association of the species with timberline throughout British Columbia, and Soper (1964) noted a similar relationship in Alberta. Most writers mention swift, clear, spring-fed or glacial streams with gravelly bottoms, spring seeps in moss beds, and growth of shrubby alpine willow (see our Figure 2) Hof $\mathrm{fman} \& \mathrm{Pat}$ a $\mathrm{e}$ (1968) give the lower altitudinal limit of the species in Montana as $5000 \mathrm{ft}$. $(1525 \mathrm{~m})$. However H ooven $(1973)$ and Maser \& Hooven (1970) record the species along streamsides in the Oregon Cascades in regenerating logged areas at $2250 \mathrm{ft} .(686 \mathrm{~m})$ elevation, and $R$ a c e $y(1960)$ reports that during population eruptions in the Cascades in British Columbia it may be found in the valleys to only $600 \mathrm{ft} .(183 \mathrm{~m})$ above sea level. Racey implies that when population density increases, occupied habitat may extend to steep grassy slopes, and mentions invasions of cultivated fields (alfalfa and potatoes). F ind le y (1951) also remarks on unusual occurrences of $A$. richardsoni in relatively dry alpine meadows".

The habitat descriptions available for Arvicola terrestris, in comparison with those available for $A$. richardsoni, show both similarities and differences. While both species are markedly amphibious, and $A$, terrestris, like $A$. richardsoni, prefers streams with little fluctuation in water level ( $Z$ e jda \& Z a p let a l, 1969), the former also occupies the banks of lowland streams and lakes, and populates wet meadows, marshes and reed beds ( $\mathrm{g} \mathrm{n}$ e $\mathrm{v}, 1950)$. Traps set in wet meadows at Plateau Mountain did not capture any $A$. richardsoni, even along the margins of pools of standing water. $\mathrm{Z}$ ejda $\& \mathrm{Z}$ a ple $\mathrm{ta} \mathrm{I}$ (1269), also note that $A$. terrestris prefers streams with muddy bottoms and turbid water, and suggest a general avoidance of those streams with rocky or sandy bottoms and dense shrubby growth along the banks.

On the basis of our observations, and the literature, it appears that A. richardsoni is specific to the ecotone between montane forest and alpine tundra under normal conditions. The association with cold streams has been noted repeatedly Hollster, 1912; Bailey, 1936 and Anderson, 1959) and low water temperature may be of particular significance. We have noted the soil in the runways frequently appears 
to be saturated. Water content of soil, atmosphere, and vegetation may all be important to the species.

The riparian habitat at timberline may have a combination of highly specific characteristics, such as high humidity and high soil moisture in summer and prolonged annual winter snow cover associated, in particular, with low and relatively constant summer temperatures. Low summer nocturnal temperatures would result from the flow of cool air from adjacent mountain slopes downwards along stream gulleys. In association with the cold stream flow, this air movement would produce a microclimate of consistently low temperature. Under these conditions the season of plant growth is very short. During the brief summer period vegetation becomes lush in comparison with that on adjacent siopes. $\hat{\Lambda}$ similar association of microclimate, soil moisture, and vegetation growth may have provided an extended periglacial habitat for $A$. richardsoni during glacial intervals. At present it may characterize a set of niche dimensions within which the species competes successfully with more widely distributed forms.

Most observers have reported a predominance of forbs in the diet of $A$. richardsoni (e.g. Hollis ter, 1912; Cow an \& Munro, 1945). Cowan \& Guiget (1960) specifically comment that little grass or sedge is consumed. Our data suggest that in summer forbs are supplemented with grasses and terminal branches of alpine willow. Although two grasses made up the major numerical component of cuttings collected at Highwood Pass (Table 2), grasses and sedges contributed vittle by weight in analysis of cuttings collected at Plateau Mountain (Table 3).

$\mathrm{H}$ ansson (1971) has shown that water needs and micronutrient requirements for small vegetation-eating mammals may be quite specific. If $A$, richardsoni is relatively specialized, concentration on forbs may strongly influence population size and distribution. In contrast, $A$. terrestris consumes primarily grasses, rushes, and sedges $(Z$ e j d a \& Zapletal, 1969; Holišova, 1970; S toddart, 1970) as do Microtus pennsylvanicus and Microtus longicaudus $(\mathrm{Z}$ imm e $\mathrm{rman}, 1965$; Anderson, 1959). Microtus pennsylvanicus shows a preference for introduced grasses (Thompson, 1965). Members of the genus Microtus, of course, do show dietary flexibility. For example $M$. californicus may resort to a seed diet during dry periods (B a tzli \& Pitelka, 1971).

The majority of plant species appearing in our collections of cuttings at Highwood Pass and Plateau Mountain are not restricted to the riparian biotope, although they may grow more densely and produce more vegetative growth near the streams. These observations do not, however eliminate the possibility that, in combination, food plant species, plant growth patterns, and microclimate may not provide a unique set of habitat conditions. 
Interspecific competition is often suspected as a factor in limited ecological and geographic distribution. It is clear that a number of widely distributed species are not excluded from the habitat of $A$. richardsoni by trophic or microclimatic factors. Several of these species (Microtus longicaudus, $M$. pennsylvanicus, Phenacomys intermedius and Clethrionomys gapperi) probably have some food-niche overlap with. A. richardsoni and a potential for competitive exclusion can therefore be assumed.

Panteleyev (1968) and Panteleyev \& Terjechina (1968) have discussed the relationship between body size, habitat, and association with water in $A$. terrestris. They note that populations at low elevations (flood plains) are most aquatic and have the largest average body length, while those from subalpine habitats are least aquatic and have the smallest average body length. They recognize subalpine populations as, a separate subspecies. A. terrestris scherman. The proposal is advanced that as a general principle, body size is positively correlated with the degree of adaptation to aquatic activity. If a large body size gives A. richardsoni a competitive advantage in the immediate riparian environment (low temperatures, high humidity, movement in and through swift-flowing cold water, heavy and prolonged winter snow cover) the species may be able to hold its own against competition under these specific conditions. Elsewhere, however, it may be excluded by competitive interactions with one or several of the more broadly adapted forms.

If the above interpretation is correct, why has not a similar restriction occurred in the case of Arvicola terrestris? One possibility is that the presently greater ecological amplitude and adaptive modalities of the latter species reflect the different ecological and biogeographic histories of North America and Eurasia during the later part of the Pleistocene. In Eurasia the combination of the East-West barrier of the Mediteiranean, the East-West cordillera, and the continental glaciation advancing from the North, may have created a region from which smaller, less water and cold-adapted, microtines were excluded, or within which they were at a competitive disadvantage for significant periods. Such a situation would have provided ancestral populations of Arvicola with the freedom to evolve a larger ecological amplitude during a time when they were not subject to intense competition. Given this sevolutionary space $A$. terrestris might subsequently have been able to retain a wider ecological and geographic distribution, and even expand into new areas and habitats in the face of renewed competition from the varied smaller vole species. In North America the North-South trending cordillera would not have created an opportunity for a similar adaptive history for Arvicola. Instead, although there may have been a periglacially 
greater extent of the biotope than we now see, there was less opportunity for expansion and consolidation of the ecological niche. This could have resulted in the present restriction of $A$. richardsoni to a very specific set of habitat conditions where large body size provides a significant competitive advantage.

\subsection{Reproduction, Dispersion, Social Relationships and Dispersal}

The habitats to which Arvicola richardsoni is restricted at most times are small in area, and discontinuous. Each is linear and dendritic, following the courses of favourable stretches of stream. It appears that local populations are generally Iikely to be small, a conclusion supported by most trapping records (e.g. Holl is te r, 1912; R a c e y \& Cow an, 19.36; Hooven, 1973). During the short snow-free season when the food situation is presumably favourable, these habitats are separated by expanses of inhospitable forest, dry meadow, scree, roek, or lowland. During the winter months they are separated by a snow-buried landscape. Small population size inevitably increases vulnerability to extinction at the local level. Production and dispersal of young in the short snow-free period are crucial adaptive problems under these conditions.

On the basis of our data from 1972, the breeding season in A. richardsoni is relatively short. Young had not yet entered the trappable population at either Highwood Pass or Plateau Mountain in the first week in July 1972, although they must have appeared shortly thereafter. The length of gestation has not been determined for $A$. richardsoni, but it is 20-22 days in A. terrestris ( $\mathrm{S}$ tod da $\mathrm{t}, 1971$ ). Assuming a similar gestation in $A$. richardsoni, and allowing 14 days for weaning of young (Skirrow, 1969), breeding would have begun in the first week in June when habitats at both sites were still snow covered. Since one male and one femäle in the overwintered-adult class were marginally active in August, the breeding season may have been drawing to a close. Breeding would thus have lasted between two and one-half and three months. This approximates the pattern reported by Stoddart for Arvicola in Scotland, where births were aggregated into three main groups in a fashion similar to that which we have observed ( $S$ tuddart, $1970 ; 1971)$. A. richardsoni may, however, have a higher reproductive potential than the Scottish $A$. terrestris, since in Scotland young of the year do not reproduce in the year of their birth. In our study females of the first litter of the season were pregnant in August. At lower elevations, the breeding seasons of the North American species which we have found co-occurring with $A$. richardsoni are generally consid- 
erably longer. In the Kananaskis area, however, Sloan (1967) found that while Peromyscus maniculatus females were pregnant in early May at elevations of $4-5000 \mathrm{ft} .(1200-1500 \mathrm{~m})$, pregnant females did not appear until mid-June at the elevations where $A$. richardsoni occurs. At the higher elevation, the Peromyscus breeding season was thus at least as restricted as that of $A$. richardsoni when subject to the same climatic regime, and Peromyscus young of the year did not become pregnant.

Litter size, as determined by foetal counts, has been reported for A. richardsoni by a number of authors (C ow an \& Guiget, 1960; Soper, 1964; Racey, 1960; Racey \& Cowan, 1963; Cowan \& Mun ro, 1945). When our own observations are averaged with those obtained from the above publications the average litter size for $A$. richardsoni (6.0) falls within the range reported for $A$. terrestris (S tod d a r t, 1971).

To this point the respect in which the reproductive biology of $A$. richardsoni is striking is the apparent absence of males in the first litter produced by the overwintering females. Although there appears to be statistical justification for considering this to be due to something other than sampling error, its basis cannot be evaluated at this time. Two interesting possibilities occur to us. The more probable is that, on reaching sexual maturity, the males of this earliest litter disperse. An alternative possibility is that all young in the first litter are in fact females. This possibility is raised by the peculiar sex ratios observed in the wood lemming, Myopus schisticolor (K a le la \& Ok a$\mathrm{la}, 1966 ; \mathrm{Frank}, 1966)$. In the case of $A$. richardsoni the production of a high proportion of females early in the breeding season, followed by a reproductive contribution from these same females, could be of considerable adaptive value since the time available for reproduction and dispersal of young is severely restricted.

The home range of $A$. richardsoni may be considerably smaller than ' that of $A$. terrestris. Only the inter-capture distance of adult males approximates the average linear extent of trap-revealed home range in A. terrestris $(\overline{\mathrm{x}}=119 \mathrm{~m})$ reported by $\mathrm{S}$ tod d a I $\mathrm{t}(1970)$.

Our observations suggest the following pattern of dispersion and social organization in $A$, richardsoni during the summer months. It appears that each overwintered individual has a linear home range along the stream. No overlap was observed among the home ranges of overwintered females or among those of overwintered males. Within each sex therefore it appears that overwintered individuals are territorial. The home ranges of overwintered males are larger, and each observed male home range overlapped the range of one of the overwintered 
females. There was overlap between the occurrence of young of the year and the ranges of overwintered individuals of both sexes. Sexually active females of the first litter of the season co-existed with sexually active overwintered females. Young of the second and third litters of the season occurred in clusters in late August, presumably retaining their natal association and co-existing with ovèrwintered incividuals of either sex. This provides an indication of the social relationships and organization along a typical headwaters stream. Two to three overwintered females occupy mutually exclusive home ranges. In each area we observed that the range of the single overwintered male overlapped that of an overwintered female. Two to three females from the first litter of the season, and the young of two subsequent litters were also present. It can be speculated that the movements of the overwintered male along the stream course provide social integration of this group. Such a pattern of social organization cannot be fitted precisely into either the classification provided by Eise n berg (1965) or that of $\mathrm{F}$ is ler (1969). In Eisenberg's terminology, the social pattern in $A$. richardsoni best conforms to the description of a polygamous family band type of communal social system (forced into a linear configuration by the restrictive habitat requirements). In the Fisler scheme, the pattern would be classified as a hierarchical spatial territory, assuming that the overwintered male is socially dominant over those individuals with overlapping ranges.

In conjunction with the linear pattern of organization; there are suggestions that the movement of water in the stream may play an important role in social integration. Sk ir row (1969) observed that in large experimental pens, where animals were able to establish runway systems, $A$. richardsoni was markedly less aggressive towards both conspecific neighbours and unfamiliar conspecifics than was the case with Microtus pennsylvanicus, $M$. longicaudus, or Clethrionomys gapperi in the same situation. In the case of. A. richardsoni, encounters generally resulted in avoidance behaviour, following which the resident individual(s) would go to a water bowl and urinate in the water. In both $A$. richardsoni and $A$. terrestris there is an extreme development of flank glands (Q u a y, 1968; S toddart, 1972). B a il ey (1900). refers to a musk producing anal gland in addition to the flank gland in A. richardsoni. Stoddart, in his 1972 review of the use of the scent organs in A. terrestris, cites V r tis (1930a) to the effect that secretion of the lateral scent organs in that species is oily, and floats on the surface of water. Vrtiš apparently proposed that this scent might attract females to males for breeding purposes (the gland is more highly developed in males, and according to $\mathrm{Stoddart} \mathrm{(1972)} \mathrm{is} \mathrm{responsive} \mathrm{to} \mathrm{male} \mathrm{hor-}$ 
mones). Vrti š (1930b) also appears to have suggested (vide Stoddart) that the flank gland might have a territorial function.

A. terrestris establishes well developed latrine sites ( $\mathrm{Stoddart}$, 1970). Stoddart (1972) cites the observation by Frank (1957) that the secretion of the flank glands is "transferred to the range boundary at latrine sites and during defecation by a scratching action of the hind feet*. Chemical communication appears to take a different form in $A$. richardsoni. We have found no evidence of latrine sites of $A$. richardsoni in the field. On the contrary, fecal pellets are only rarely encountered, and when found appear generally to be solitary. A captive male, kept in a terrarium in our laboratory, defecated and urirated in the pan of water supplied. S k i r r o w (1969) has noted a similar tendency. The implications of these observations is that downstream transfer of pheromones released from flank or anal glands, or associated with excretory products, could serve to transmit information (e.g. sexual receptivity of upstream females, or presence of territorial adult males). Stream flow could thus play a significant role in integration of groupings and governance of dispersal in A. richardsoni.

It is appropriate to emphasize here that we have no firm information on habitat or social relationships during the "winter" months when our study areas are buried in deep snows. Winter flooding and freezing, with a build up of ice on the ground surface, is common along small streams like those where $A$. richardsoni occurs. Such ice formation would unavoidably cause dislocation of the animals from summer home range. Seasonal changes in habitat have been reported for many vole species, including $A$. terrestris (e.g. M y $11 \mathrm{ymäki}$, 1969). In each of our study areas we have observed one or two well drained banks a few meters from the streams which showed evidence of heavy winter grazing by voles. Associated with the heavy grazing are extensive systems of large, unused burrows and runways. This may evidence a winter change of habitat, and the possibility of winter aggregations.

The existence of snow cover (eight to ten months of the year in our study areas) is likely to hinder dispersal movements. Assuming young animals are more likely to disperse than adults, the time avallable for dispersal and establishment of new home ranges unhindered by snow would be only two months (mid-July through early September). In August, the second and third litters of the season appeared to be in residence near their natal sites. The remaining time available for snowfree dispersal for these individuals was one month or less.

\subsection{Population Density}

The population densities which we have observed fall close to the 
average values for the smaller microtines, and are somewhat higher than might be expected for ecological generalists (e.g., Peromyscus) in North America. We have been unable to find in the literature any figures for the density of Arvicola terrestris in situations closely comparable to our study areas. In comparison with what appeared to be routine $A$. terrestris populations of 50 to 250/hectare (M y ll y mäk i. 1969 ), the $A$. richardsoni densities are relatively low. There appear to be no data in the literature for densities of $A$. richardsoni during $"$ population explosions $*$. R a cey (1960), in referring to such outbreaks, does not give figures.

\subsection{Biochemical Variation}

The high levels of variability and heterozygosity revealed by biochemical techniques have recently been the center of a great deal of interest and controversy. Theoretical formulations (e.g., L e v in s, 1968; GiIlespie, 1974) and accumulating data (Selander \& Kauf$\mathrm{mann}, 1973$ ) have led to emphasis on the role of environmental heterogeneity. These authors postulate that in species in which the size of the individual is small, and the environment is experienced as temporally and/or spatially patchy, small size and lowered mobility should be associated with greater genic variability. Among the points made by Selander \& $\mathrm{Kaufmann}$ (1973), the following are pertinent to the $A$. richardsoni case. (1) Gene flow does not appear to be a requirement for the maintenance of variability since high levels of polymorphism and heterozygosity can be maintained in its absence. (2) Excluding small insular populations, and those having recently experienced severe reductions in numbers, there is no apparent relationship between the level of genic variability and the total number of individuals in the species, or the geographic range of the species.

The available evidence suggests that $A$. richardsoni inhabits islands of favourable habitat which are isolated (in terms of the apparent obstacles to dispersal). It also suggests that, although densities are equivalent to those commonly observed in microtines, the number of individuals in each habitat "island" is relatively small. These factors, in accord with slightly larger size, suggest that $A$. richardsoni might be expected to show somewhat less variation than smaller, more uniformly distributed congeners. On the other hand, extremes of temporal variation in the conditions of the habitat between the short and verdant alpine summer and the long winter (the seasonal aspect of environmental heterogeneity) might make a strong contribution to variability. In a previous paper (Anderson, 1970) the senior author has explored some of the implications and apparent consequences of 
seasonal heterogeneity in the environment with respect to rodent populations. The English language literature on seasonal phenomena in microtines has recently been expanded significantly by $\mathrm{B} \mathrm{rown} \mathrm{(1973),}$ ard Berry \& Murphy (1970) have demonstrated effective seasonal shifts in selection with respect to biochemical polymorphism in the house mouse on Skokholm Island. Thus, while small numbers and apparent isolation in $A$, richardsoni populations should indicate a reduction of variability and heterozygosity, the extreme variation in the seasonal environment might be expected to inorease it.

While the preliminary nature of our data on biochemical variation in A. richardsoni limits its comparative value, we have presented, in Table 10, a comparison between our c'ata and that available for several more wel known species and we comment below on the comparative aspects of structure and variation in each.

House mice (Mus musculus) may form behaviourally isolated family groups which maintain genetic individuality in either spatially heterogeneous or spatially homogeneous environments (Anders on, 1964, 1965, 1970; Petras, 1967a, 1967b; Selander, 1970). This local heterogeneity co-exists with regional patterns of geographic variation, showing clines suggestive of the operation of selection and gene flow in the classic sense (Selander \& Yang, 1969, Selander, 1970). The house mouse is an opportunistic and colonizing species. It appears to exhibit considerable plasticity in social structure (A n de rs on, 1961). Where habitats are discrete, a demic or "Grossfamilie* structure may develop ( $\mathrm{E}$ i b l-E i b es f el d t, 1950). This may maintain a high degree of genetic individuality for each group, and may have significant effects on the distribution, frequency, and dynamics of some alleles (L ewontin \& Dunn, 1960; L ewontin, 1962, Anderson, 1965, 1970; Petras, 1967a, 1967b). Founder effects may also be significant as new habitats are discovered and exploited by a few colonists carrying a non-representative component of the parental gene pool (S e la n d e r, 1970). It appears, however, that the opportunity for reorganization of gene pools under the small-population, founding group structure may be limited if genes are packaged in co-adapted blocks (as suggested by Selander, Hunt \& Yang, 1969). In continuous habitats there is evidence that behavioural structuring may still impede gene flow and lead to genetic structuring (Anderson, Dunn \& Beasley, 1964; Selander, 1970) although Myers (1973) failed to find evidence of genetically effective structuring in a salt marsh population and disputes the structuring concept.

The genus Peromyscus has been widely studied both ecologically and genetically and its biology has been reviewed in book form ( $\mathrm{K}$ ing. 


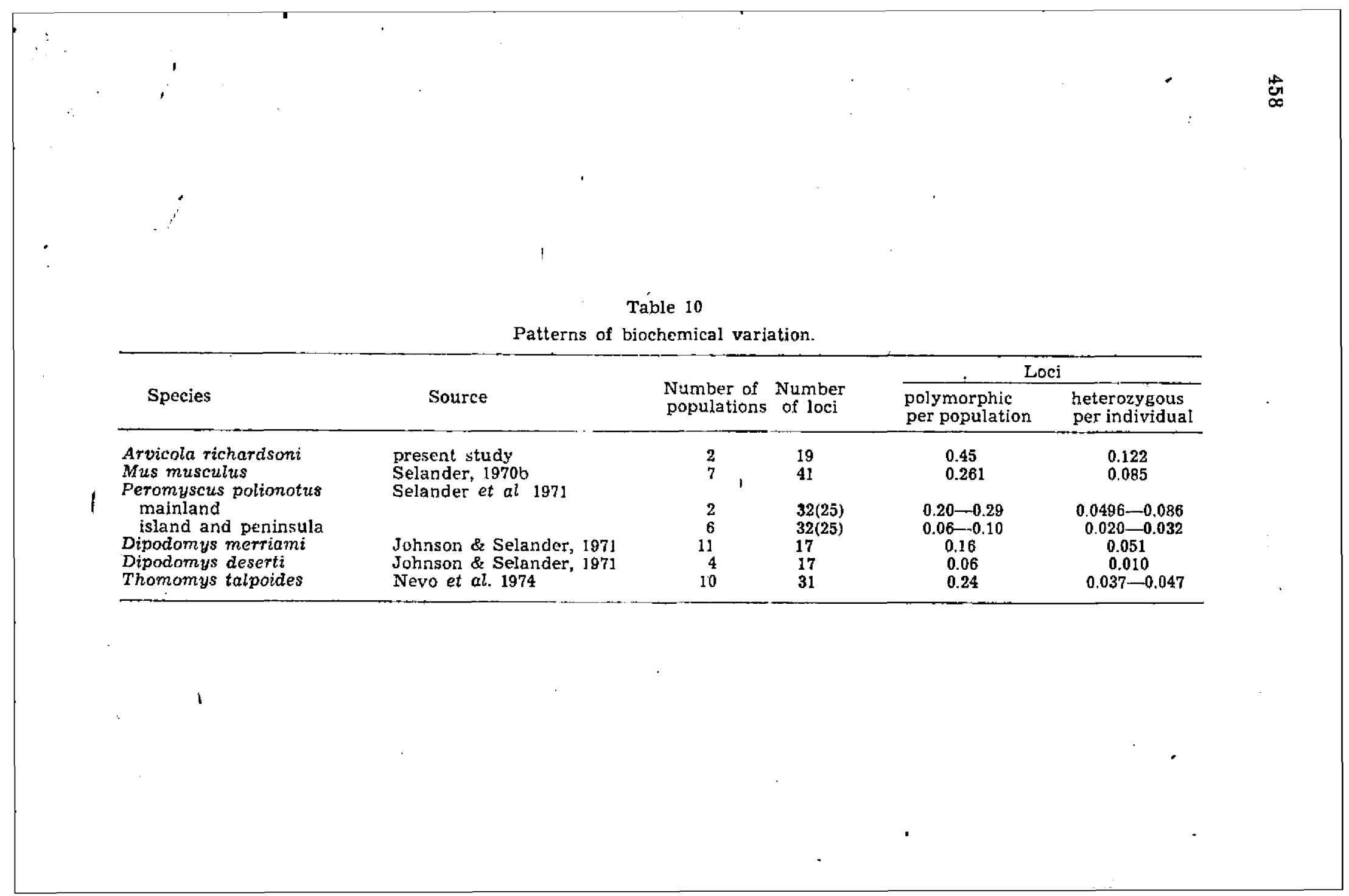


1968). Members of the genus are primarily granivors and are found throughout almost all of North and Middle America. Peromyscus maniculatus, the species which co-occurs with Arvicola richardsoni in our study area, is the most widely distributed of Peromyscus species and has an extremely broad ecological amplitude, occupying habitats ranging from desert through grassland to eastern deciduous forest, boreal forest, and west-coast rain forests, to alpine tundra. The extent of the range of Peromyscus maniculatus, and the extreme degree of morphological variation, have so far precluded any definitive evaluation of its biochemical variation. We have therefore turned to the study of S elander et al. (1971) on variation in the old-field mouse, Peromyscus polionotus, for comparative purposes. In this species, breeding structure seems to be based on a more nearly monogamous relationship than is the case with $P$. maniculatus, but in other respects there is considerable similarity.

In their analysis of 32 scorable loci, Sel ander et al. found $53 \%$ to be polymorphic in one or more populations, but the proportion of loci polymorphic was as low as $6 \%$ in island isolates and reached a maximum of $29 \%$ in any one sample. There was a significant geographical variation - in average heterozygosity, which was lowest on an isolated island where the population was thought to pass through occasional bottlenecks due to hurricane-induced mortality. Variation was intermediate on peninsulas, highest in mainland populations. There was a regional cline in mean heterozygosity $(\vec{H})$ and it was suggested that this might relate to the diversity of habitat subtypes occupied. Peromyscus polionotus ceems to provide strong evidence for the role of spatial heterogeneity (1) in inducing genetic diversity (through heterogeneity. in the quality of occupied habitats) and (2) in limiting genetic diversity (through barriers to gene flow or the limiting and drift-inducing effects of limitation on population size in small arepas of habitat). Although comparable in size and food habits to house mice, members of the genus Peromyscus do not show the same colonizing ability.

Like mebers of the genus Peromyscus, kangaroo rats (Dipodomys) do not show a high degree of colonizing potential. They do however have a considerable potential for long distance dispersal. Most significantly, they are notable among the species discussed here in that they may hibernate and/or estivate. Seasonal inactivity may thus limit the temporal diversity of the environment which they experience.

The social behaviour of heteromyids has been extensively studied by $\mathbf{E}$ is e $\mathrm{n} b \mathrm{~b} \mathbf{g}$ (1963) who assigns all members of the genus to a closed dispersed social system" in which adults are solitary, and aggressive towards conspecifics except when mating or in mother-young associations. 
Tohnson \& Selander (1971) have done an extensive survey of biochemical variation in the genus, finding that Dipodomys are among the less variable of the rodent groups so far studied. Not only is the proportion of loci which are polymorphic relatively low, but for most of the polymorphic loci the same allele predominates throughout the species range. Relative allelic frequencies estimated on the basis of one or two samples anywhere in the species range appear to be valid in gencral for a particular species at most loci.

Some differences observed among Dipodomys species are pertinent to the present discussion. Dipodomys merriami, a species with broad habitat tolerances, and Dipodomys deserti, a habitat specialist with a geographic range similar in size to that of $A$. richardsoni, illustrate these trends. While there is no relationship between genetic variability and the extent of geographic range, it appears there may be a positive correlation between variability and ecological amplitude. John s on \& S elander (1971) suggest that variations in soil quality may be the most significant indicator of amplitude in habitat. In the more specialized Dipodomys deserti the proportion of loci polymorphic per population, and the proportion of loci heterozygous per individual, are considerably lower than in the generalist Dipodomys merriami.

Despite the evidence for a dispersed and solitary type of social organization, Johnson \& Selander (l.c.) note that in Dipodomys merriami "some degree of genetic structuring apparently exists" because mosaic patterning with respect to biochemical variants can be seen in local areas. They suggest that this may indicate inbreeding, perhaps caused by a tendency for dispersing young to settle near the point of birth.

$N$ e vo et al. (1974) have recently published a study of genetic variation in the Thomomys talpoides complex of pocket gophers in the southern Rocky Mountains. These highly fossorial animals are widely distributed over a great geographic and altitudinal range, and through a great variety of plant communities. Most evidence indicates that adult pocket gophers are solitary and territorial, conforming to the closed dispersed social system of Eisenberg (1963). Because of the extreme adaptation for burrowing, vagility is low. Large streams, rocky ranges, and areas with unfavourable soil may fcrm effective barriers to dispersal. However, the subterranean environment may be less variable in respect to diel and seasonal cycles, and latitudinal and altitudinal change, than that above the ground surface.

There are no direct measurements of effective population size in Thomomys, but $\mathrm{Nevo}$ et al. believe it is weither medium or large involving hundreds to thousands of individuals judging from the number of 
fresh mounds, digging activity, and trapping sucess". Although these are poor measures of the number of individuals in panmictic populations, the conclusion of large effective population size seems to be supported genetically.

In the Thomomys talpoides complex, eight of 31 loci examined were monomorphic in all populations, and all populations were fixed for the same allele in seven of the eight cases. Polymorphism was weak in 21 of the 23 polymorphic loci and there was a tendency for the same allele to be predominant or fixed in-most populations. What heterczygosity existed was contributed by a few loci. A remarkable point is that this relatively low biochemical variability was expressed in a group which has been considered highly variable morphologically, and within which eight distinct karyotypes, each tending to karyotypic homozygosity over broad geographic areas, can be recognized. This is in contrast with Dipodomys, where karyotypic and biochemical variability are positively correlated. In Thomomys, as in Dipodomys, however, rare alleles tend to show mosaic patterns in local distribution and this may be indicative of some social involvement in patterning of gene flow.

$\mathrm{N}$ e v o et al. favor the conclusion that the relatively low level of genic variability in the Thomomys talpoides complex is related to "selection for homozygosity in the narrow-niche and relatively constant subterranean environment «. A number of arguments are advanced against explanations based on founder effects, drift, ar genic neutrality. In effect, the evidence gathered and the arguments presented support the view that local structuring of populations by either behavioural or extrinsic factors has little evolutionary significance.

Our data on variation in Arvicola richardsoni are fragmentary, and the loci with which we have been able to work to date should not be considered a random sample, but Table 10 indicates that Arvicola richardsoni is relatively variable despite the small size of local populations and the seemingly considerable obstacles to dispersal. The major difference in the environmental factors with which $A$. richardsoni must contend, and those faced by the other species reviewed in the text and in Table 10 is the extreme seasonal heterogeneity which is experienced.

Johnson \& Selander (1971) suggest four categories of factors which might influence the relationship between the genetic variability of a species and its habitat diversity.

1. Specialized species might have smaller effective population size.

2. Specialized species might be more likely to pass through bottlenecks and thus lose diversity.

3. Higher diversity might be selected for as an adaptation to environmental heterogenity. 
4. Differential selection in diverse types of habitat, combined with gene flow among these populations, might promote heterozygosity in local populations.

Arvicola richardsoni is not a mcolonizing species, nor is it fossorial or hibernating, and it shows patterns of dispersion and local distribution distinct in several respects from any of the forms just discussed. Although $A$, richardsoni populations might tend to lose diversity as the result of small effective population size (1) or bottlenecks (2) and seem to be specialized with respect to habitat (4), our conclusion to this point must be that the temporal diversity of habitat (3) is overriding any combined effects of the other factors.

Most discussion of the relationship between environmental heterogeneity and genetic variability has emphasized the spatial, rather than the temporal, aspects of environmental variation. The theoretical formulations (e.g., Levins, 1968; B ry a nt, 1974), however, can be readily applied to temporal heterogeneity as experienced by rodent populations. If seasonally varying selective pressures are more significant than population subdivision in determining variability in Arvicola richardsoni, a species may have considerable flexibility in adapting population structure to environmental demands without having to face any major dislocations in the evolutionary process.

Acknowledgements: We are grateful to Donna Anderson, David B oyle, Kenneth Pers $\mathrm{S}$, and Scott $O^{\prime} \mathrm{K}$ e ef for assistance in trapping. Donna A nders on proofread the manuseript. Dr. C. D. B $1 \mathrm{rd}$ and the staff of the Herbarium at the University of Calgary assisted with plant identifications. Our work was done under a grant from the National Research Council of Canada.

\section{REFERENCES}

1. Anderson P. K., 1961: Density, social structure, and nonsocial environment in house-mouse populations and the implications for regulation of numbers. Trans. N, X, Acad of Sei. Ser, II, 23: 447-451.

2. Anderson P. K., 1964: Lethal alleles in Mus musculus: Local distribution and evidence for isolation of demes. Science 145: 177-178.

3. Anderson P. K, 1965: The role of breeding structure in evolutionary processes of Mus musculus populations. [In: "Mutation in population, Proc. Symp. 011 Mutational Process]. Prague: 17-21.

4. Anderson P. K., 1970: Ecological structure and gene flow in small mammals. Symp. zool. Soc. Lond., 26: 299-325.

5. Anderson P. K., Dunn L. C. \& Beasley A. B., 1964: Introduction of a lethai allele into a feral house mouse population. Am. Nat. 98: 57-64.

6. Anders on S., 1959: Distribution, variation, and relationships of the montane vole, Microtus montanus. U. of Kansas Publication, Mus. of. Nat. Hist., $y$ : 415-511.

7. Baig M., 19i2: Ecology of timberline vegetation in the Rocky Mountains $J f$ Alberta. Ph. D. Thesis. Univ. of Calgary: $1-444$. 
8. Bailey $V_{r}$, 1900: Revision of American voles of the genus Microtus. N Amer. Fauna, 17: 1-88.

9. Bailey V., 1936: The mammals and life zones of Oregon. N. Amer. Fauna, 55: $1 \ldots 416$.

10. Berry R. J. \& Murphy H. M., 1970: The biochemical genetics of an island population of the house mouse. Proc. Roy. Soc. Lond., B 176: 87-103.

11. B r own, Ernest B. III. 1973. Changes in patterns of seasonal growth of Microlus pennsylvanicus. Ecoiogy 54: 1103-1110.

12. Bryant E. H., 1974: On the adaptive significance of enzyme polymorphisms in relation to environmental variability. Am. Nat. 108: 1-19.

13. Carter N. D. \& Parr C. W., 1967: Isoenzymes of phosphoglucose isomerase in mice. Nature, 216:511.

14. Cowan I. McT. \& Guiget C, J., 1960: The mammals of British Columbia. British Columbia Provincial Museum: 1-413. Victoria.

15. Cowan 1. McT. \& Mun ro J. A., 1945: Birds and mammals of Revelstoke National Park. Can. Alp. J., 29; 100-121.

16. Eibi-Eibesfeldt, l., 1950: Beiträge zur Biologie der Haus und der Alirenmaus nebst einigen Beobachtungen an anderen Nagern. Z. Tierpsychol. 7: $558-587$.

17. Eisenberg. J. F., 1963: The behaviour of Heteromyid rodents. Univ. Calis. Publ. Zool., 69: 1--100. Berkeley.

16. E is e nberg J. E., 1966: The social organizations of mammals. Handb. Zoo! $8(10)$, sect. $7: 1-92$.

19. Ellerman J. R. \& Morrison-Scott T. C. S., 1951: Checklist of Palaearctic and Indian mammals. British Museum (Nat. Hist.): 1-810. Londoa.

2u. Findley J. S., 1951: Habitat preference of four species or Microtus it Jackson Hole, Wyoming. J. Mamm. 32: 118-120.

21. Fisler G. F., 1969: Mammalian organizational systems. Contrib. in Sci., Los Angeles County Museum, 167: 1-32.

22. Frank F., 1957: Das Duft markieren der Grossen Wühlmaus, Arvicola terrestris (L.). Z. Säugetierk., 21: 172-175.

23. Frank F., 1966: Verschiebung des Geschlechtsverhältnisses in der WühlmausGruppe (Microtidae). Naturwissenschaften 53: 90-91.

24. Gaines M. S, \& Krebs C. J., 1971: Genetic changes in fluctuating vole populations. Evolution, 25: 703-723.

25. Gillespie J., 1974: Polymorphism in patchy environments. Amer. Nat.. 108: $145-151$.

26. Hansson L, 1971: Small rodent food. feeding and population dynamics. Oikos, 22: 183-198.

27. Hoffmann R. S. \& Jones J. K. Jr., 1970; Influence of late-glacial and post-glacial events on the distribution of recent mammals on the northern great plains. [In: Pleistocene and Recent Environments of the Central Great Plains". Dort, W. and J. Knox Jones eds.] Publication 3, Dept. of Geology, Univ. of Kansas, Lawrence.

28. Hof $f$ man R. S. \& Pattie D. L., 1968: A guide to Montana mammals, Univ. of Montana: 1-133, Missoula.

29. Holišova V., 1970: Trophic requirements of the water vole, Arvicola terrestris Linn, on the edge of stagnant waters. Zool. Listy 19: 221-233.

30. Hollister N., 1912: Mammals of the Alpine Club expedition to the Mount Robson region. Can. Alp. J., Sp. No., 1912: 1—75. 
31. Hooven E. F., 1973: Notes on the water vole in Oregon. J. Mamm., 51; $751-753$.

32. Johnson W. E. \& Selander R. K., 1971: Protein variation and systematics in kangaroo rats (genus Diporomys). Syst. Zool., 20: 377-405.

33. Kalela $O$. \& Oksala T., 1966: Sex ratio in the wood lemming, Myopus schisticolor (Lilljeb.), in nature and in captivity. Annls Univ. Turkuensis, ser. A, II, Biol., 37: 1-24.

34. K ing J., ed. 1968 Biology of Peromyscus (Rodentia). Sp. Pub. No. 2 Am. Soc. Mamm. I-593.

35. Kristjansson F, K., 1963: Genetic control of two pre-albumins in pigs. Genetics, 48: 1059-1063.

36. Levins R., 1968: Evolution in changing environments: some theoretical explorations. Princeton Univ. Press: 1-120. Princeton, N. J.

37. Lew ont in R. C., 1962: Interdeme selection controlling a polymorphism in the house mouse. Am. Nat. 96: 65-78.

38. Lew ontin R. C. \& Dunn L. C, 1960: The evolutionary dynamics of a polymorphism in the house mouse. Genetics, 45: 705-722.

39. Maser C. \& Hooven E. F., 1970: Low altitude records of Microtus richardsoni in the Oregon Cascades. Murrelet, 51: 12.

40. Myers $5, H, 1973$ : The absence of $t$-alleles in feral populations of house mice. Evolution, 27: 702-704.

41. Myllymäki A., 1969: Trapping experiments on the water vole Arvicola terrestris (L.) with the aid of the isotope technique. [In: "Energy flow through small mammal populations», Eds. Petrusewicz K. \& Ryszkowski L.], PWN Polish Sci. Publ.: 39-56. Warsaw.

42. Nevo E., Kim Y. J., Shaw C. R. \& Tha eler C. S. Jr., 1974: Genetic variation, selection and speciation in Thomomus talpoides pocket gophers. Evolution, 28: 1-23.

43. Ognev S. I., 1950: Mammals of the U.S.S.R. and adjacent countries. Israel Program for Scientific Translations, Jerusalem 1964. 7; 1-626.

44. Panteleyev F. A., 1968: Population ecology of water voles and measures of control. Izd. Nauka: 1-256. Moskva.

45. Panteleyev P. \& Terjechina A. N., 1968: The landscape variability of the water vole (Arvicola terrestris L.) as a new form of animil spatial variability. Zool. Ž. 47, 4: 610-617.

46. Petras M. L., 1967a: Studies of natural populations of $M u s$. I. Biochemical polymorphisms and their bearing on breeding structure. Evolution, 21: 259 -274 .

47. Petras M. L., $1967 \mathrm{~b}$. Studies of natural populations of Mus. II. Polymorphism at the $T$ locus. Evolution, $21: 466-478$.

46. Qu ay W. B., 1968: The specialized posteriolateral sebaceous glandular regions in microtine rodents. J. Mamm., 49: 427-445.

49. Racey K., 1960: Notes relative to the fluctuation in numbers of Microtus richardsoni richardsoni about Alta Lake and Pemberton Valley, B. C. Murrelet, 41: $13-14$.

50. Racey K. \& Cowan J. McT., 1936: Mammals of the Alta Lake region of southwestern British Columbia. Rept. Prov. Mus. B. C. for the year 1935: $15-29$.

51. Rasmussen D. L. \& Chamberlain N. V., 1959: A new Richardson's meadow mouse from Utah. J. Mamm., 40: $53-56$. 
52. Rasmussen D. I. \& Koehn R. K., 1966: Serum transferrin polymorphism in the deer motuse. Genetics, 54: $1353-1357$.

53. Roderick T. H., Ruddle F. H., Chapman V. M. \& Shows T. B., 1971: Biochemical polymorphisms in feral and inbred mice (Mus musculus). Biochemical Genetics 5: $457-466$.

54. Ruddle F. H. \& $\mathrm{Nichols}$ E. A., 1971: Starch gel electrophorelic phenotypes of mouse $X$ human somatic cell hybrids and mouse isozyme polymorphisms. In Vitro, $7: 120-131$.

55. Selander R. K., 1970: Behavior and genetic variation in natural populations. Amer. Zool., 10: 53-66.

56. Selander R, K, 1970b: Biochemical polymorphism in populations of the house mouse and old-field mouse. Symp. zool. Soc. Lond. 26: 73-9i.

57. Selander R. K., Hunt W. G. \& Yang S. H., 1969: Prctein polymorphism and genic heterozygosity in two European subspecies of the house mouse. Evolution, 23: 379-390.

58. Selander R. K. \& Yang S. Y., 1969: Protein polymorphism and genetic heterozygosity in a wild population of the house mouse (Mus musculus) Genelics, 63: 653-667.

59. Selander R. K. \& Y ang S. Y., 1970: Biochemical genetics and behavio: in wild house mouse populations. [In: "Contribution to behavior-genetic anaIysis: the mouse as a prototypen, Eds. Lindzey G. \& Thiessen D. D.): 293 334. Appleton-Century-Croft, New York.

60. Selander R. K. \& Ka ufmann D. W., 1973: Genic variability and strategies of adaptation in animals. Proc. Nat. Acad. Sci., 70: 1875-187\%.

6t. Selander R. K., Smith M. H., Yang S. Y., Johnson W. E. ix Gentry J. B., 1971: Biochemical polymorphism and systematics in the genu: Peromyscus. I. Variation in the old-field mouse (Peromyscus polionotus). [In: "Studies in genetics $\alpha]-$ U. Tex. Publ.: 49-90. Austin.

62. Skirrow M., 1969: Behavioural studies of five microtine species. Ph. D Thesis, Univ. of Calgary: 1-211.

63. Sloan R., 1967: A survey of altitudinal variation in reproduction in $P e-$ romyscus maniculatus. M. Sc. Thesis, Univ. of Calgary: 1-82.

64. Soper .T. D., 1964: The mammals of Alberta: 1-402. Edmonton.

65. Stoddart D. M., 1970: Individual range, dispersion and dispersal in a population of water voles (Arvicola terrestris (L.)). J. Anim. Ecol., 39: 403-425.

66. Stoddart D. M., 1971: Breeding and survival in a population of water voles. J. Anim. Ecol., 40: 487-494.

67. Stoddart D. M., 1972: The lateral scent organs of Arvicola terrestris (Rodentia; Microtinae). J. Zool., Lond., 166: 49-54.

68. Thom pson D, Q., 1965: Food preferences of the meadow vole (Microtus pennsylvanicus) in relation to hapbitat affinities. Amer. Midl. Nat. 74: 76-86.

69. Trottier G. C., 1972: Ecology of the alpine vegetation of Highwood Pass, Alberta. M. Sc. Thesis. Univ. of Calgary: $1-229$.

70. Whitaker J. O., 1966: Food of Mus musculus, Peromyscus maniculatu; batrdi and Peromyscus leucopus in Vigo County, Indiana. J. Mamm., 47: 473 $-486$.

7!. Walker E. P., 1964: Mammals of the World "Johns Hopkins Press: Vol. 2 : $647-1550$. Baltimore.

72. Wijngaarden A. van, 1954: Biologie en bestrijding van de woelrat, 
Arvicola terrestris terrestris (L.) in Nederland. Meded. plziektenk. Dienst Wageningen, 123: 1-147.

73. Worral C. H. B., 1962: Trapping and keeping water voles, Arvicola terrestris amphibius L. Proc. zool. Soc. Lond., 140: 334-336.

74. Zejda J. \& Zapletal M., 1969: Habitat requirements of the water voli (Arvicolo terrestris Linn.) along water streams. Zool. Listy, 18: 225-238.

76. $\mathrm{Z} \mathrm{imm} \mathrm{erman} \mathrm{E.} \mathrm{G.,} \mathrm{1965:} \mathrm{A} \mathrm{comparison} \mathrm{of} \mathrm{habitat} \mathrm{and} \mathrm{food} \mathrm{of} \mathrm{two} \mathrm{specie:}$ of Microtus. J. Mamm., 46: 605--612.

Accepted, December 31, 1975.

Paul K. ANDERSON, Paul H. WHITNEY i Jean-Pierre HUANG

ARVICOLA RICHARDSONI: EKOLOGIA I BIOCHEMICZNY POLIMORFIZM W SRODOWISKACH SKRAJNYCH

\section{Streszczenie}

W Albercie (Kanada) Arvicola richardsoni (D eK a y, 1842) zamieszkuje tylk's srodowiska umiarkowanie wilgotne polożone wzdluz okresowo czynnych cieków na wysokosci 2000 do $2200 \mathrm{~m}$ npm w Rocky Mountain (Ryc. 1, 2). Taka ścisla spe-cjalizacja środowiskowa okresla zarówno rozmieszczenie jak i wielkość populacji miejscowych a także dyspersje w tych populacjach. W dwu miejscach, w którycì populacje byly badane, zlowiono także 6 innych gatunków gryzoni, przy czym wszystkie z nich mają znacznie szerszy zasięg geograficzny niż A. richardsoni. Porownano także zasięgi $A$. terrestris i $A$. richardsoni szukając przy tym przyczyn, które tiumaczyły by ograniczony zasięg tego drugiego gatunku (Tatele 4, 5). Dokonano także próby określenia stosunków pokz:mowych (Tabela 2, 3). W 1973 roku rozród trwal od czerwca do sierpnia, choć przypuszczalnie zalconczył sịç dopiero $w$ polowie września. Samice-przezimki dały trzy mioty. W badanej probia wszystkie mlode $z$ pierwszego miotu byly samicami i byly ciężarne w sierpniu tego samego roku (Ryc. 3). Wskaźnik lownosci wzrastal od 200 do $300 \%$ pomiędzy poczatkiem lipca a koncem sierpnia. Zageszezenie w sierpniu wynosilo 17,6 i 32,5 osobników na ha. Zwierzęta byly aktywne w ciagu calej doby, przy czym najniższa aktywnośc notowano pomiędzy switem a godzinami poludniowymi, zas najwyższa $w$ nocy (Ryc. 4). Ruchliwóśc doroslych samców byla wyższa niż samic (Ryc. 5). Opisano też dokladniej sklad populacji sierpniowej: jej organizacje i więzy socjalne (Ryc. 6, Tabela 6).

Badane populacje byly polimorficzne pod względem loci kontrolujacych aminopeptydaze leucynowa, esterazy plazmy i krwinek czerworych (Ryc. 7, Tabele 7 , 8). Nie stwierdzono natomiast zmiennosci $w$ transferynach, hemoglobinie i izomerazach glukofosfatazowych. Poziom zmienności wewnątrzpopulacyjnej okazał się względnie wysoki, porównywalny z innymi gatunkami gryzoni, na przekór podziałowi populacji na male, izolowane grupy (Tabele 9, 10). Autorzy sugeruja, de może byc to wynikiem duzych wahan sezonowych czynników śodowiskowych, so nakłada konieczność utrzymywania się wysokiej zmienności. 


\section{APPENDIX}

Preparation of buffers and stains

\section{Buffers}

1. Tris-citrate $\mathrm{pH} 7.2$

Stock solutions:
A. 0.19 M Tris (Sigma)
B. $0.05 \mathrm{M}$ citric acid
23.0 $\mathrm{g} / \mathrm{L}$ distilled water $10.5 \mathrm{~g} / \mathrm{L}$ distilled water Mix $38.0 \mathrm{ml}$ Tris, $44.4 \mathrm{ml}$ citric acid and $417.6 \mathrm{ml}$ distilled water. Titrate with Tris to $\mathrm{pH} 7.2$.

2. Tris-citrate $\mathrm{pH} 7.6$

Stock solutions: Same as in 1.

Mix $38.0 \cdot \mathrm{ml}$ Tris, $40.4 \mathrm{ml}$ citric acid and $421.6 \mathrm{ml}$ distilled water. Titrate with Tris to $\mathrm{pH}$ 7.6.

3. Sodium Borate pH 8.7

Stock solutions:

A. $0.6 \mathrm{M}$ boric acid

B. $0.2 \mathrm{M}$ sodium hydroxide

37.1 $\mathrm{g} / \mathrm{L}$ distilled water electrolyte buffer per tray.

4. Tris-citrate pH 6.2 (Ruddle \& Nichols, 1971)

Stock solutions:

$0.223 \mathrm{M}$ Tris

$0.086 \mathrm{M}$ citric acid

in 1 liter distilled water

Adjust to pH 6.2 with sodium hydroxide.

Gel buffer: $17.5 \mathrm{ml}$ stock solution and $482.5 \mathrm{ml}$ distilled water.

Electrolyte buffer: Use stock solution as prepared.

\section{Stains}

Note: All stains should be prepared immediately before use with the exception of Buffalo Black which may be stored indefinitely.

1. Buffalo Black

Stain: $1 \%$ solution of Buffalo Black NBR (Allied Chemical) in fixing solution (acetic acid, methanol and distilled water in a $1: 5: 5$ ratio by volume). Stain may be made as a stock solution and stored in a covered flask.

Application: Cover surface of gel stain. Let stand for 15 to 20 minutes at $21^{\circ} \mathrm{C}$ Wash several times in fixing solution to clear background.

2. a-naphthyl-acetate

Stock solution of $0.4 \mathrm{M}$ Tris-HCI:

$48.4 \mathrm{~g} \mathrm{Tris}, 600 \mathrm{ml}$ distilled water and $365 \mathrm{ml}$ iN HCl. Titrate with $\mathrm{HCl}$ to pH 7.0-7.2.

Stain: $200 \mathrm{mg}$ Fast Blue RR Salt (Sigma), $20 \mathrm{ml}$ stock solution and $180 \mathrm{ml}$ distilled water. Filter solution through whatman \#1 filter paper. Add $4 \mathrm{ml}$ of a $1 \%$ solution of a-naphthyl-acetate (Sigma) in acetone.

Application: Immerse gel in stain for one to two hours at $21^{\circ} \mathrm{C}$.

3. a-naphthyl-butyrate

Stain: Same as in 2 except substitute a $1 \%$ solution of $\alpha$-naphthyl-butyrate (Sigma) in acetone for u-naphthyl-acetate.

Application: Same as in 2.

4. LAP stain (S e lander et al. 1971)

Stock solution of $0.1 \mathrm{M}$ potassium phosphate buffer $\mathrm{pH} 7.0$ :

$13.6 \mathrm{~g}$ monobasic potassium phosphate, $59 \mathrm{ml} 1.0 \mathrm{M}$ sodium hydroxide and $941 \mathrm{ml}$ distilled water.

Stain: $100 \mathrm{ml}$ stock solution, $2 \mathrm{ml} 0.1 \mathrm{M}$ magnesium chloride and $20 \mathrm{mg}$ L-leucyl- $\beta$-naphthylamide HCl (Sigma). 
Application: Immerse gel in stain for 30 to 60 minutes at $37^{\circ} \mathrm{C}$. Pipette stain into flask and add $40 \mathrm{mg}$ Fast Black $\mathrm{K}$ Salt (Dajac). Restain gel for 30 to 60 minutes at $37^{\circ} \mathrm{C}$

Note: Bands fade after several weeks

5. GPI stain (Carter \& Parr, 1967)

Stock solutions:

A. $0.3 \mathrm{M}$ Tris $\mathrm{pH} 8.0$

Titrate with concentrated $\mathrm{HCl}$ to $\mathrm{pH} 8.0$.

B. $18 \mathrm{mM}$ D-fructose-6-phosphate

disodium salt (Sigma)

C. $6 \mathrm{mM}$ NADP (Sigma)

D. glucose-6-phosphate dehydrogenase

(Glucose-6- $\mathrm{PO}_{4}$ is available from:

Sigma in vials of 250 units.

Dissolve contents of vial in $25 \mathrm{ml}$

of distilled water).

Stain: $3 \mathrm{ml}$ Tris buffer, $1 \mathrm{ml} 0.1 \mathrm{M}$ magnesium chloride,

$0.4 \mathrm{ml}$ fructose-6-PO, $0.2 \mathrm{ml} \mathrm{NADP}, 0.4 \mathrm{ml}$ glucose-6-PO,

$2 \mathrm{mg}$ MTT (Sigma) and $1 \mathrm{mg}$ PMS (Sigma).

Application: Pipette stain (about $5 \mathrm{ml}$ ) onto gel surface. Use a brush to spread stain evenly over entire surface. Incubate gel at $37^{\circ} \mathrm{C}$. in the dark for one

hour. The staining dish should be covered to prevent evaporation of the stain

Note: Gels should be typed and/or photographed directly after staining as

bands begin to fade immediately.

Naktad 810 iq0. Obj. ark. Wyd. 11.75. Maszynopis otrzymano z7.V. 1976r. Podpisano do druku 17 .VIII.1976 r. Druk ukonczono w sierpniu 1976 r. Papier druk. sat. K1. III 80 g. Format Ba F-5

. ! Blatostockie Zaklady Graficzne. Zam. 1287/76. Cena at 36.- 